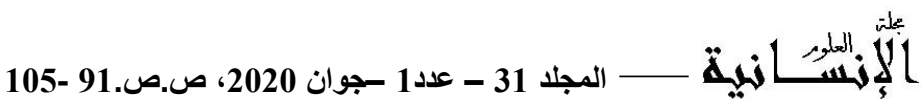

\title{
مكافحة جريمة تمويل الإرهاب في التثريع الجزائري
}

\section{Combating the crime of financing terrorism in Algerian legislation}

\author{
تاريخ الاستلام : 2020/01/09 ؛ تاريخ القبول : 2020/04/04
}

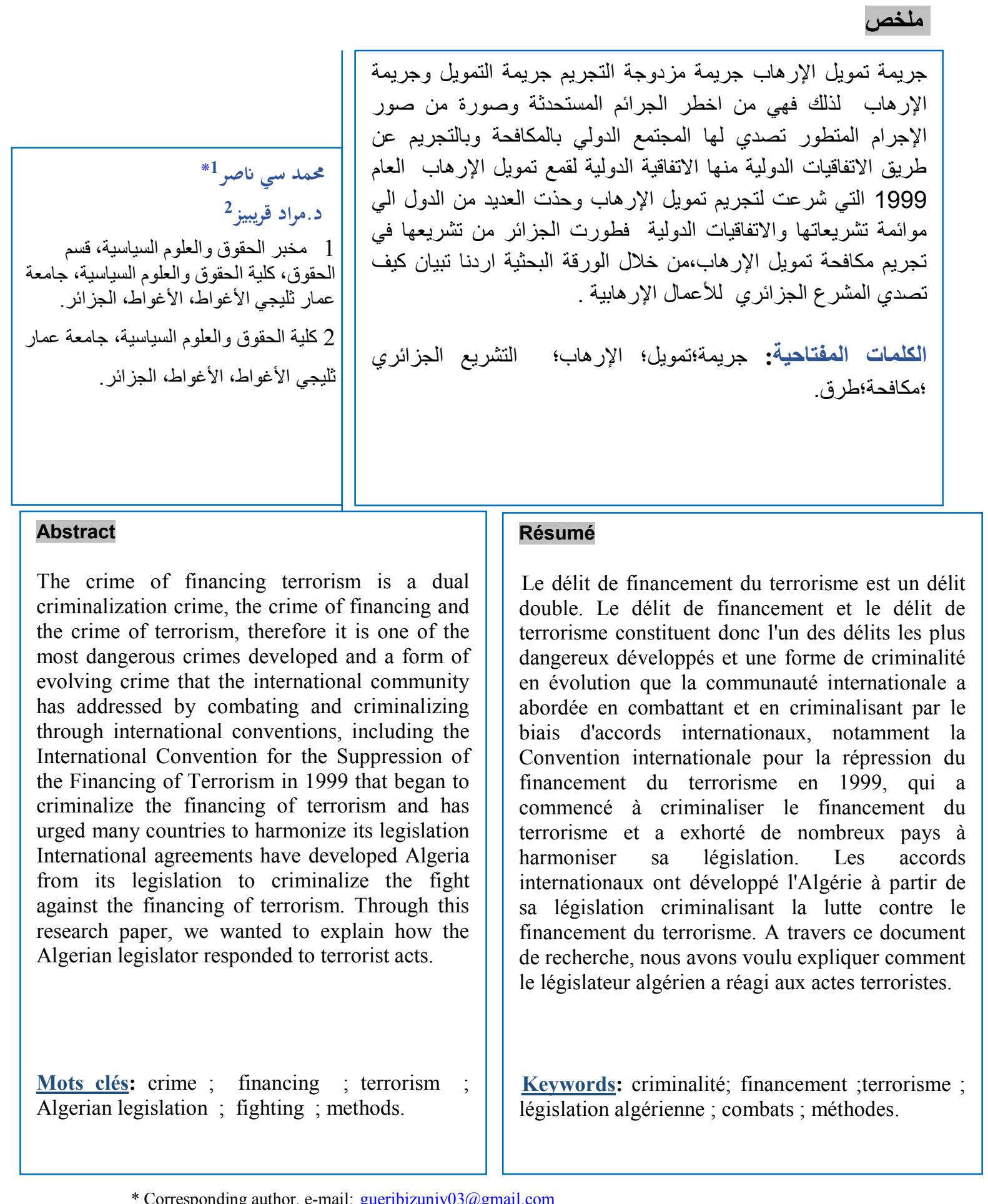

* Corresponding author, e-mail: gueribizuniv03@gmail.com

(c) جامعة الاخوة منتوري قسنطينة 1، الجزائر 2020. 
تستغل الجماعات الإرهابية الأموال مهما كان مصدر ها في تمويل العمليات سواء

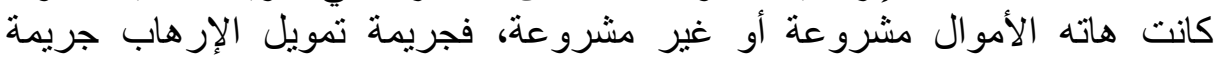

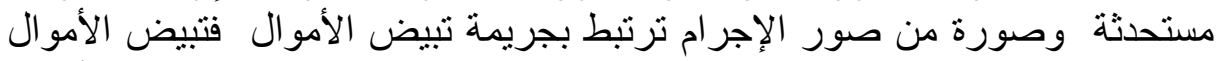

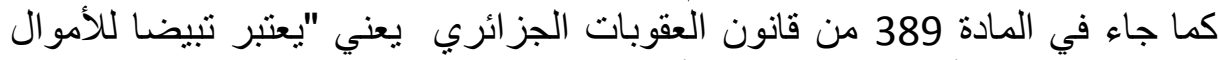

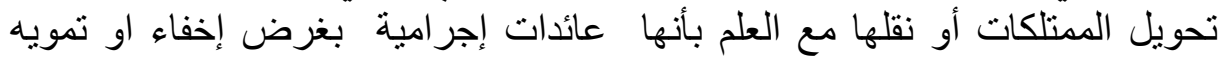

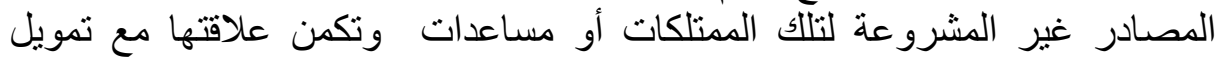

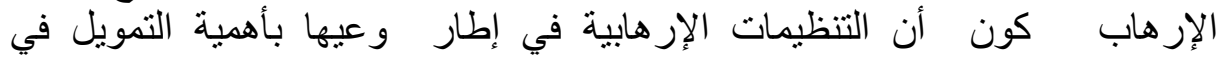

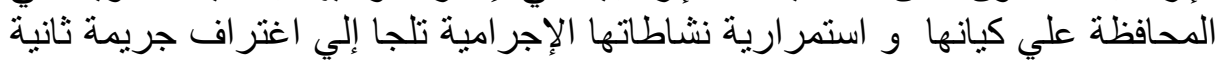

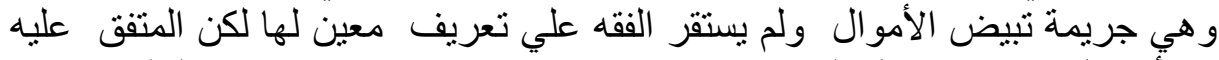

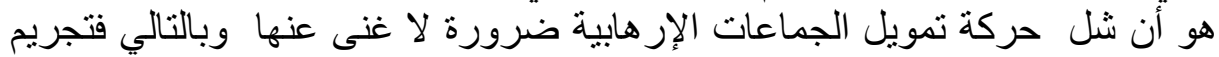

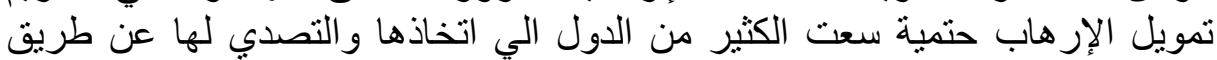

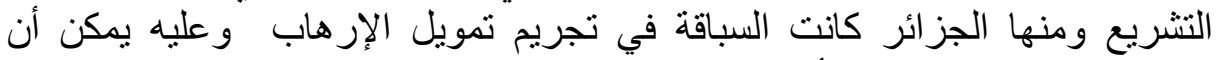

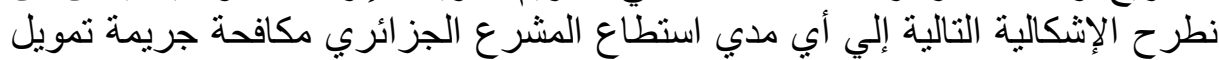

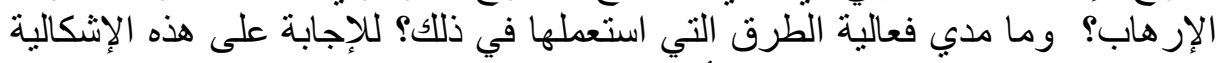

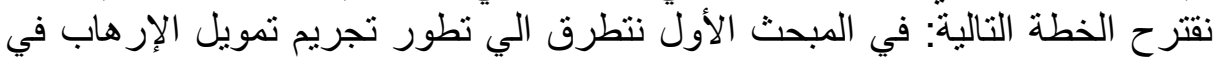

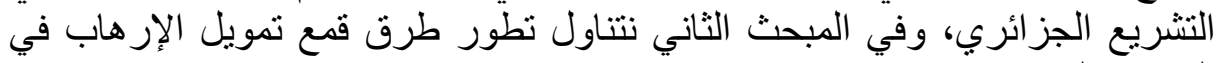
التشريع الجزائري.

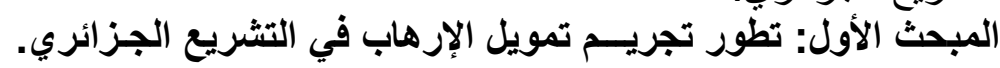

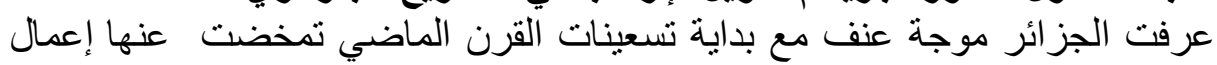

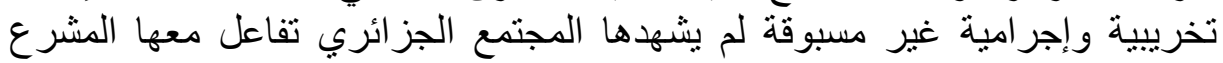

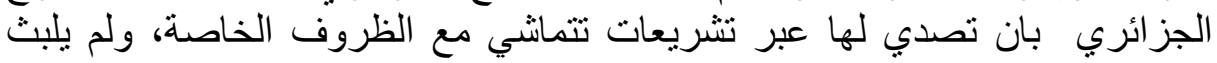

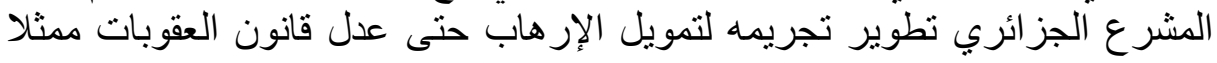

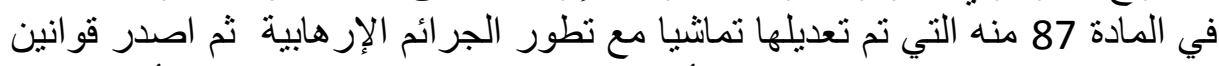

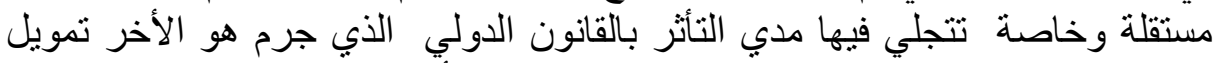

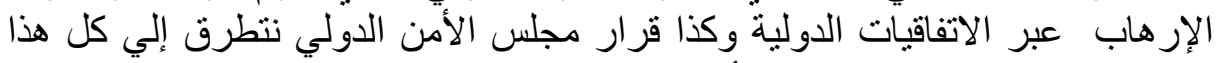

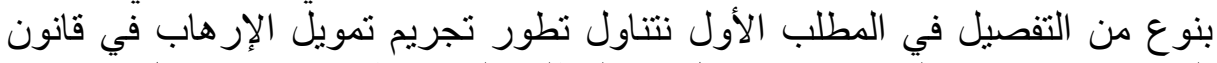

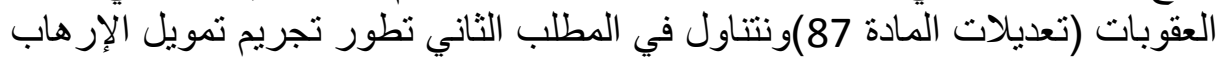
بموجب قو انين خاصة.

المطلب الأول:تطور تجريم تمويل الإرهاب في قانون العقوبات (تعديلات المادة 87).

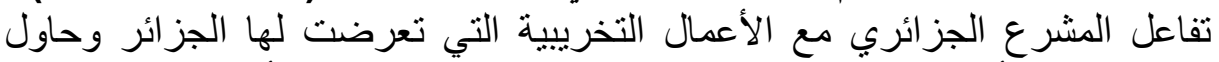

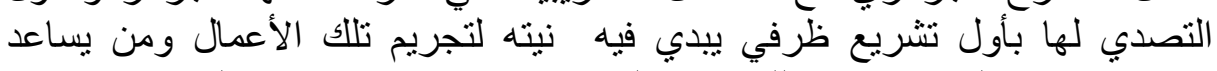

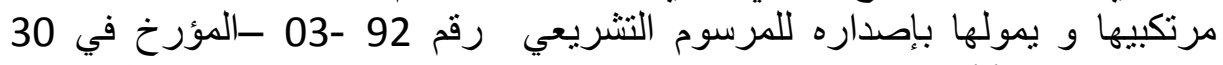

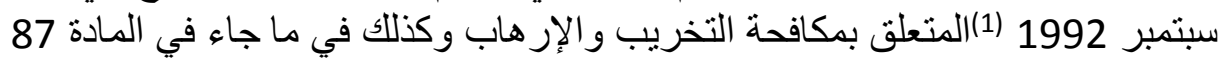

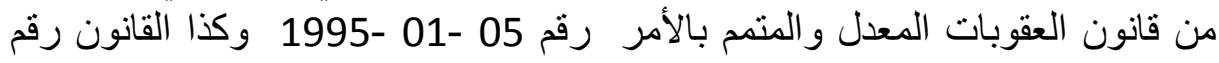

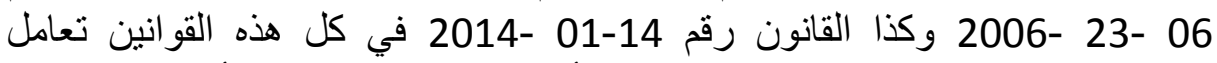
المشرع بما يسمي بالتجريم الظرفي كبدايات أولى لمحاولة الزئة الحد من الأعمال الإرهابية

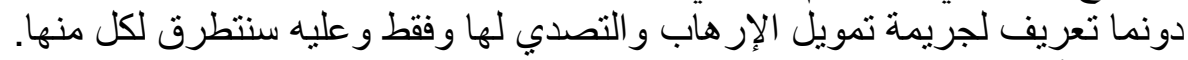

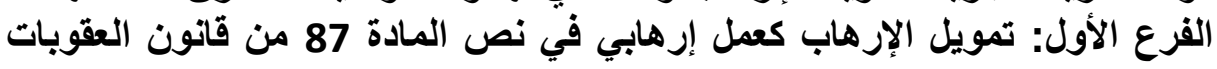

شرع في تجريم تمويل الإرهاب في التشريع الجزائري بالمرسوم التشريعي رقم

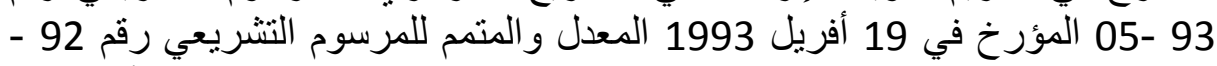

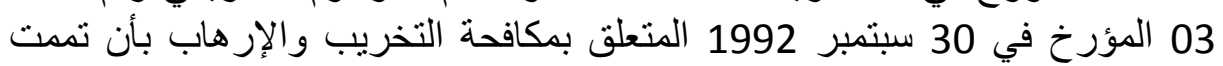


المادة الرابعة منه و أضيفت عبارة " او يثجعها بأي وسيلة كانت " لذلك تعتبر

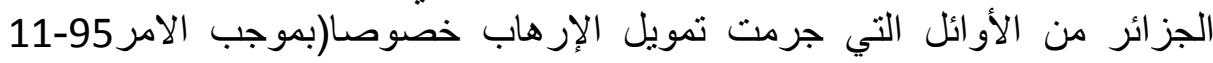

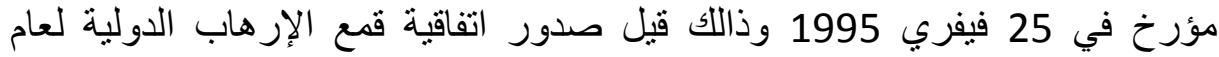

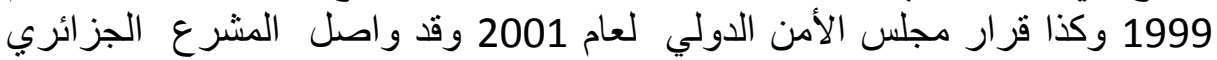

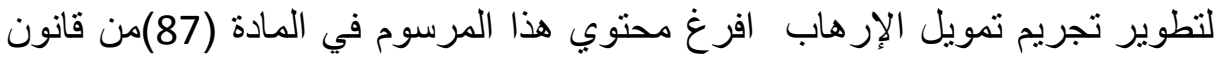

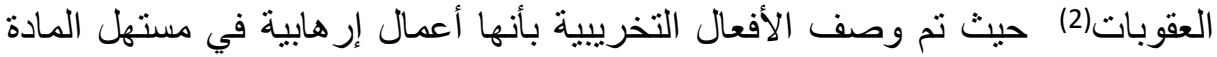

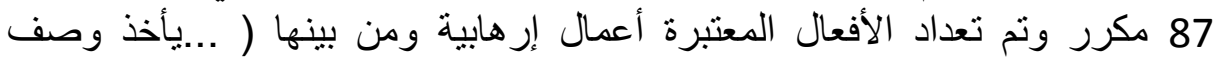

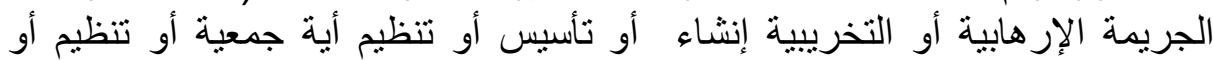

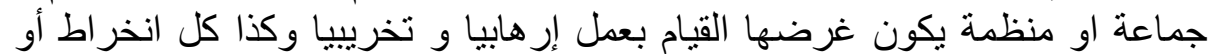

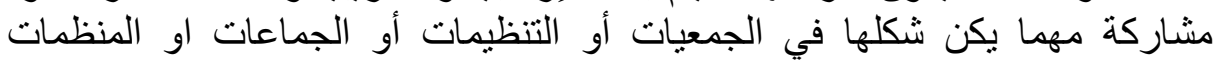

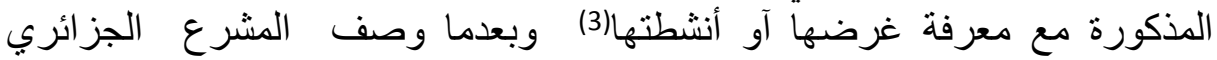

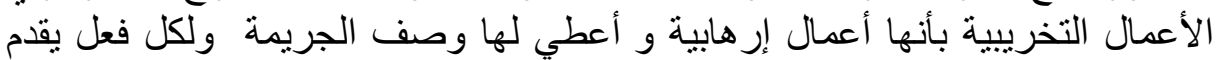

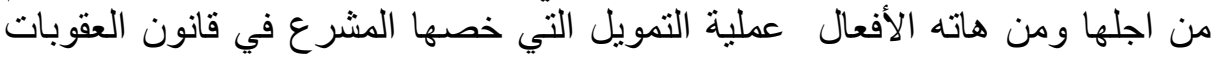

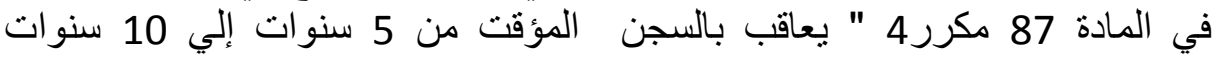

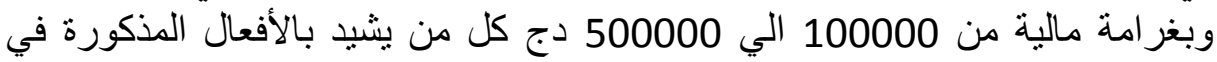

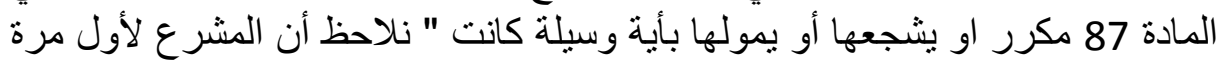

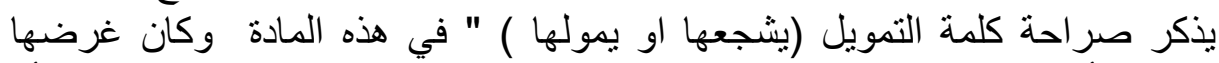

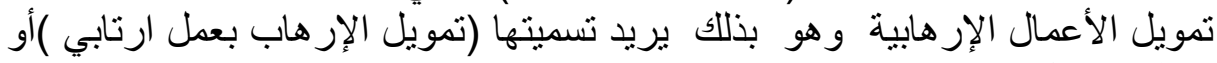

الفرع الثاني تمويل الإرهابل الارهاب بقوانين لاحقة جديدة معدلة للمادة 87 من قانون

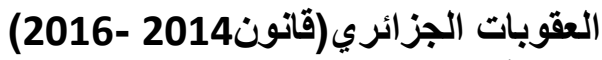

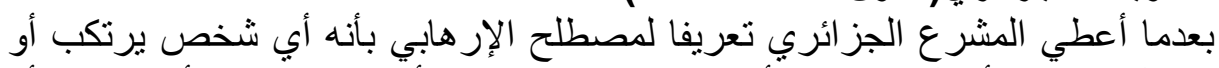

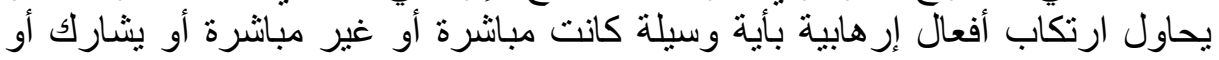
يأمر بأفعال إرهابية ويعد مشارك أك أو مساهم.

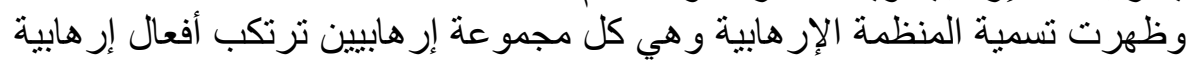

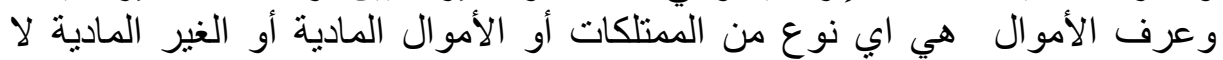

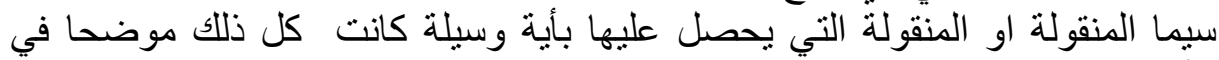

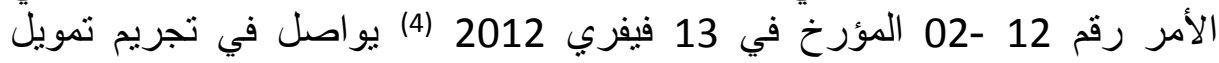

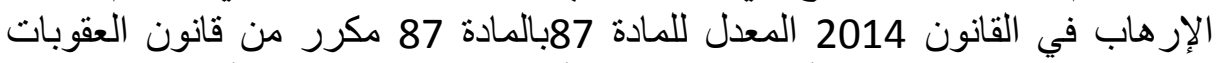

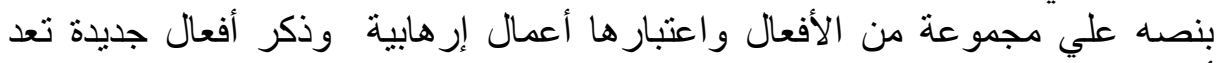

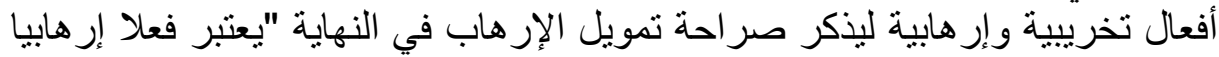

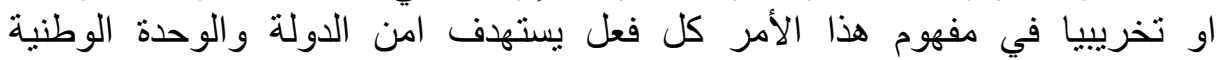

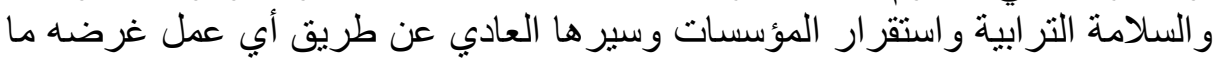
يلي:

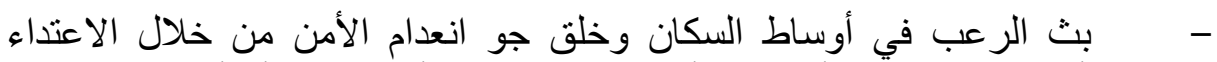

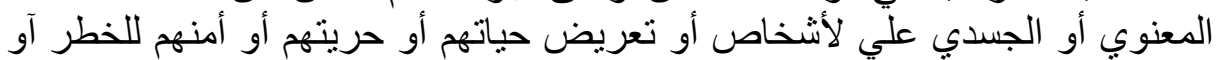
المس بممتلكاتهم.

- - - عرقلة حركة المرور أو حرية التنقل في الطريق والتجمهر او الاعتصام في الساحات العمومية.

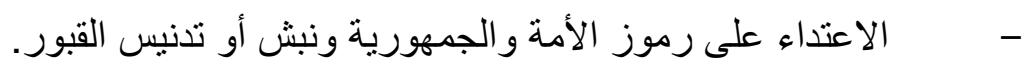

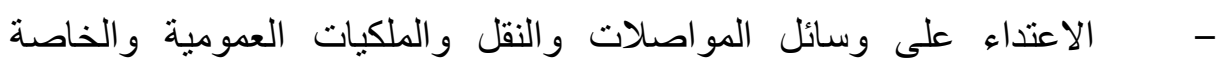
و الاستحواذ عليها او احتلالها بدون مسوغ قانلوني. 


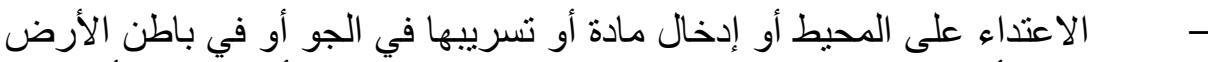

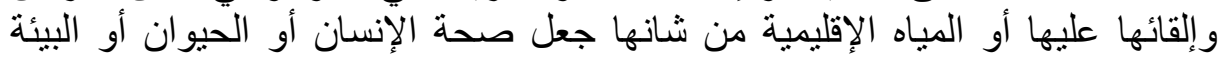
الطبيعية في خطر.

- عرقلة عمل السلطات العمومية أو حرية ممارسة العبادة والحريات العامة وسير المؤسسات المساعدة للمرفق العام.

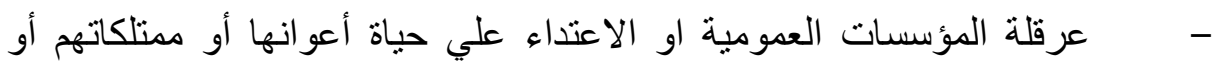
عرقلة تطبيق القو انين و التنظيمات. - - محويل الطائر ات او السفن أو أية وسيلة أخري من وسائل النقل.

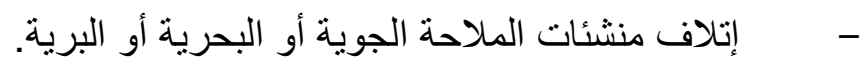
- - مخريب أو إتلاف وسائل النقل.

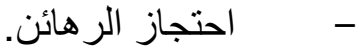
- - - المشعة. الاعتداءات باستعمال المتفجرات أو المواد البيولوجية أو الكيميائية أو النووية

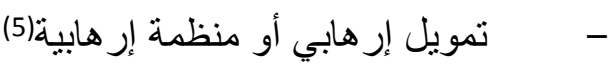

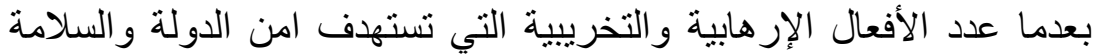

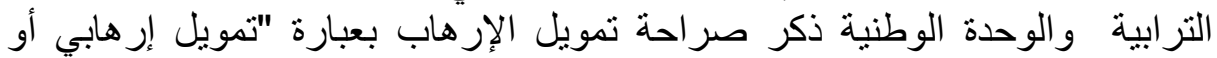

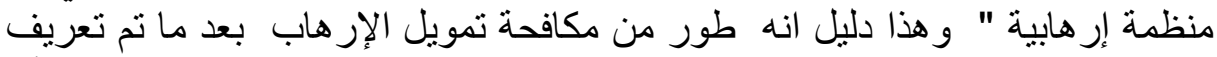

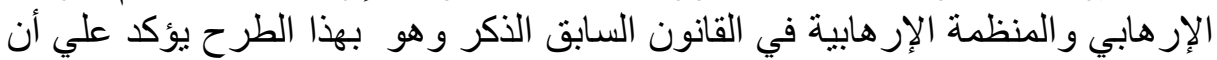

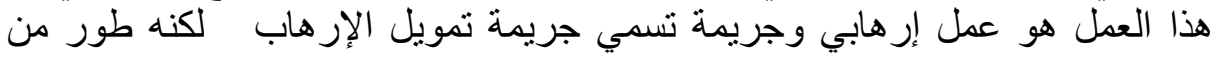

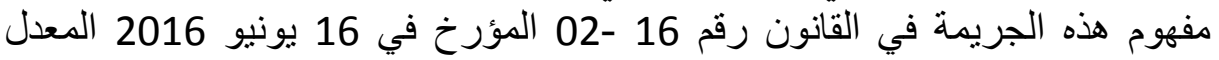

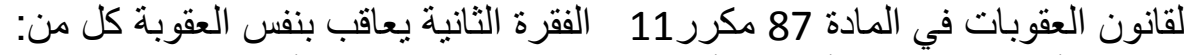

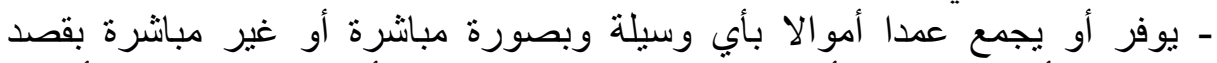

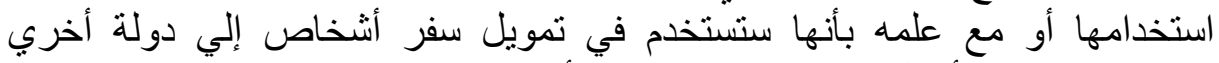
بغرض ارتكاب الأفعال المذكورة في الفقرة الأولي من هذه التهائ المادة.

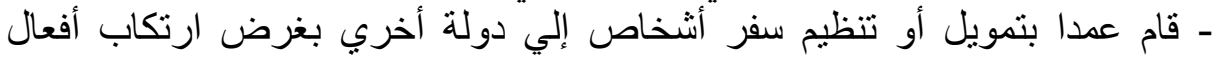

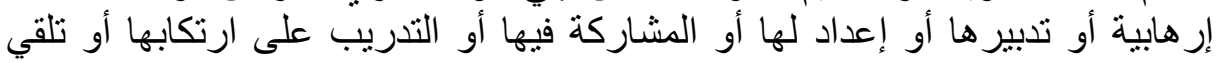
تدريب عليها او تسهيل ذلائ ألك السفر.

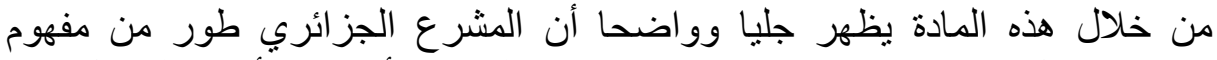

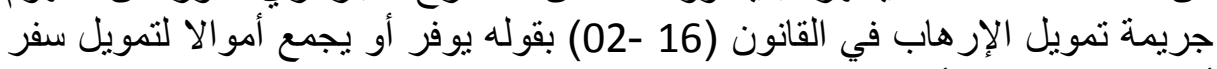

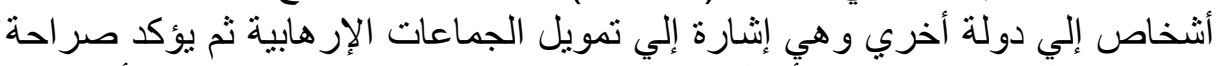

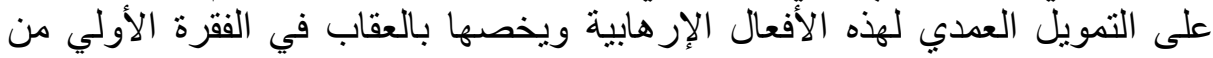

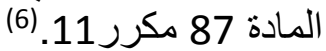
المطلب الثاني: تجريم تمويل الإرهاب بقوانين مستقلّة أو خاصة

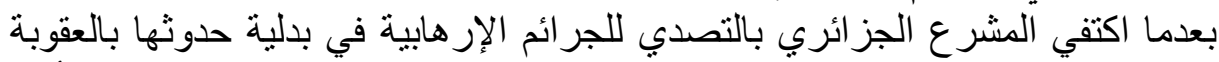

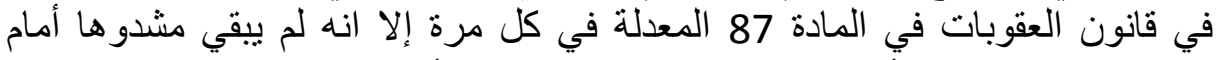

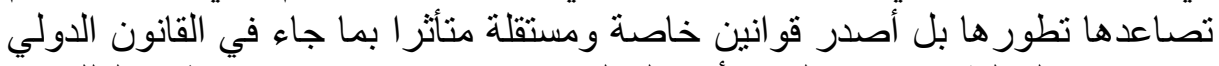

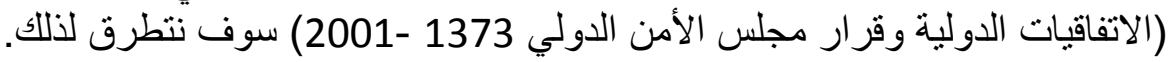


الفرع الأول: تأثير القانون الدولي على التشريع الجزائري في مكافحة تمويل

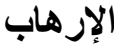
جرم القانون الدولي تمويل الإرهاب بإصداره لاتفاقيات دولية انعكست على التنشريعات

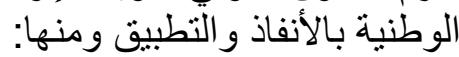
أولا: قرار مجلس الامن الألئي

قر ار مجلس الأمن الصادر بتاريخ 28 سبتمبر 2001 الزمادم جميع الدول بمكافحة تمويل

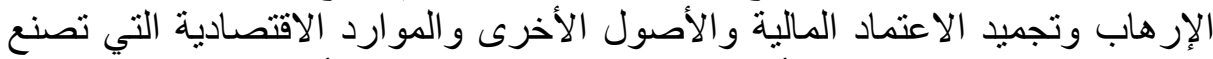

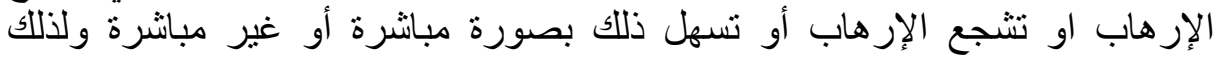
اوجب القرار الخطو ات التالية: الابل

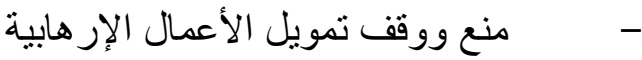
- - تجريم رعايا هذه الدول عمدا بتوفير الأموال أو جمعها بأية وسيلة بصورة مباشرة أو غير مباثرة

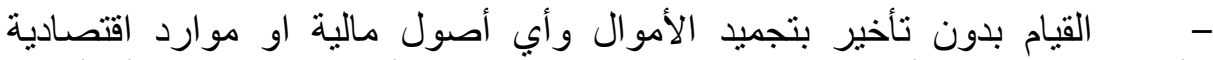

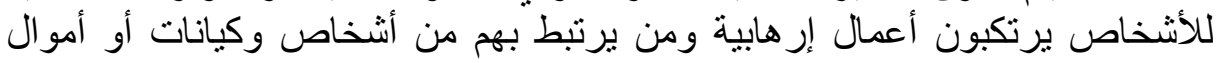
التي تدر ها هذه المتلكات - - - مفض اعطاء حق اللجوء السياسي للمشتبه في تورطهم في العمال إرهابية لو تكون لهم صلة بها

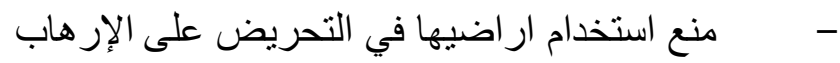

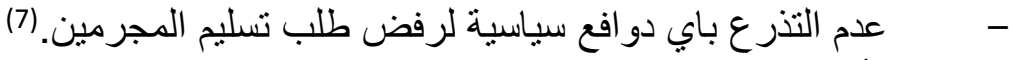

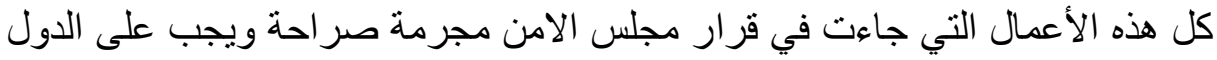
تجريمها و انفاذها في القو انين الوطنية (الموائمة).

\section{ثانيا: الاتفاقيات الاولية التي جرمت تمويل الإرهاب} 1

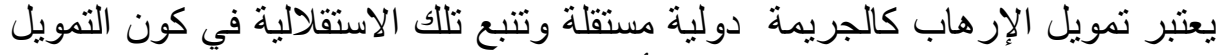

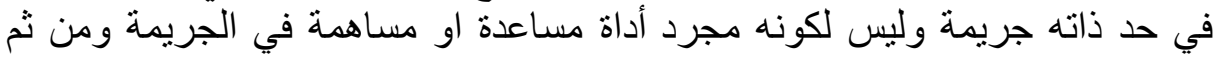
يجرم التمويل ولو لم تقع الهجمات الإرهابية(8) و هكذا فان من شاندان استقلانلية التمويل

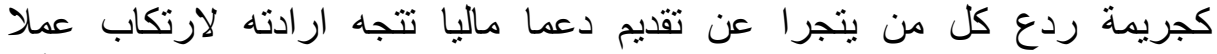

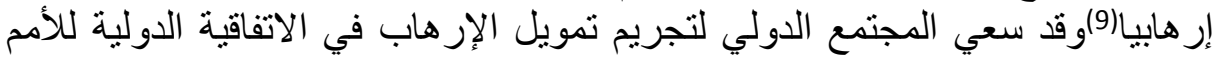

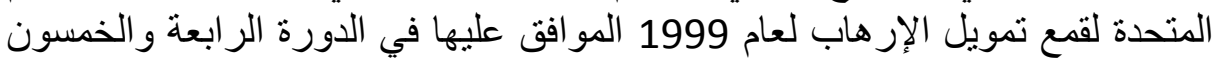

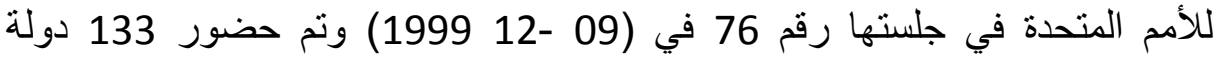

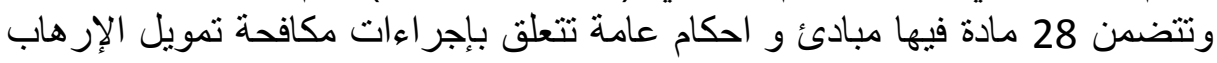
الدولي وتتضمن احكام تتعلق بتجريم تمويل الإرهاب.

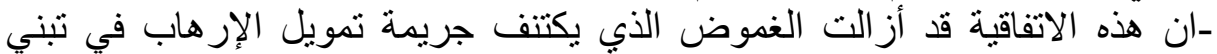

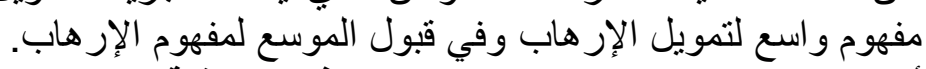

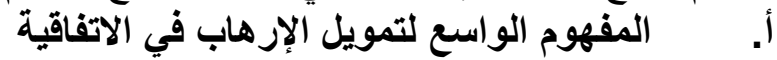

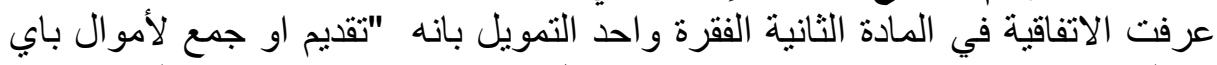

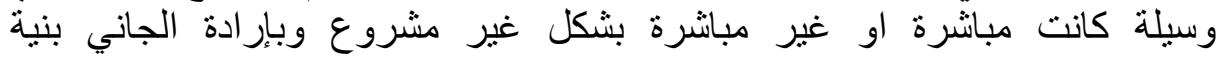

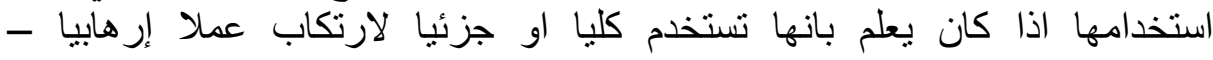
"(20) الحقيقة ان تعريف التمويل شكل محور نقاش حاد في الثناء الاشغال التحضيرية إنابية 
لإعداد الاتفاقية فقد برزت الحاجة الي توسيع مفهوم التمويل من خلال المشروع الذي بالتي

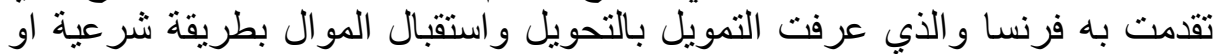

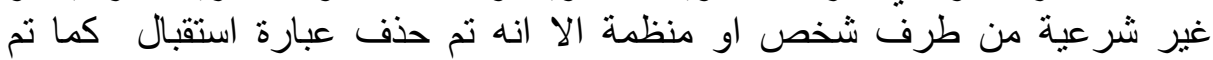

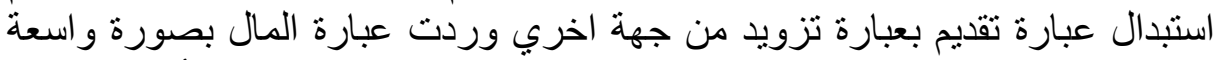

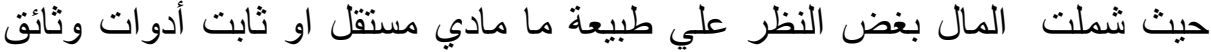
شر عية وباي شكل كانت الكترونية رقمية.

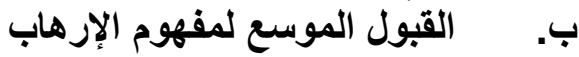
لقد شملت اتفاقية قمع تمويل الإرهاب العمل الذي يدخل في نطاق الداب احدي المعاهدات

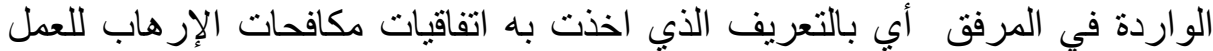

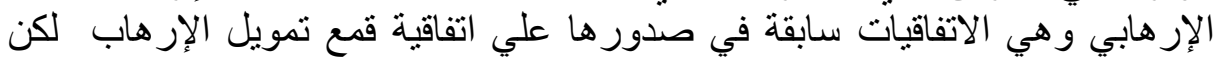

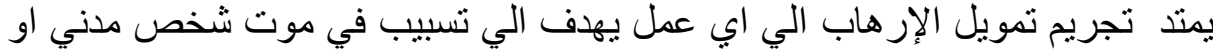

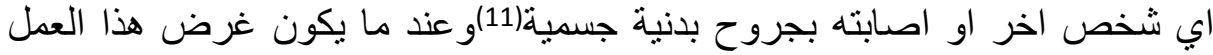

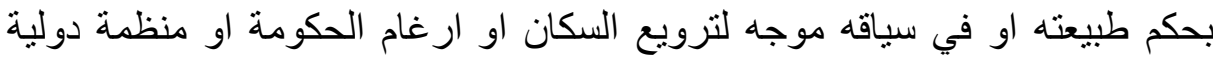

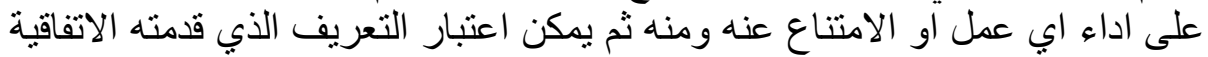

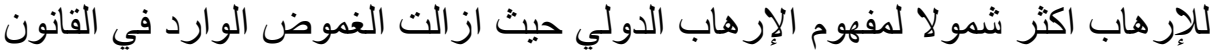

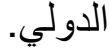

ومن الاتفاقيات الاقليمية التي جرمت تمويل الإرهاب الاتفاقية العربية لسنة 1998

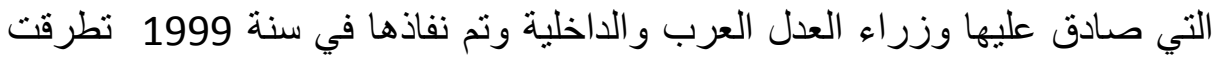

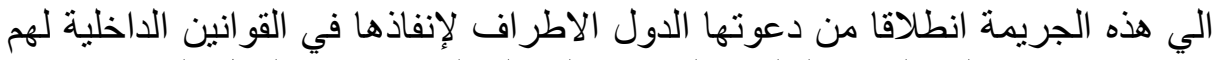

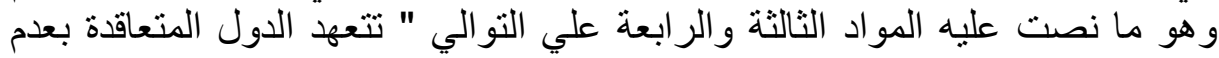

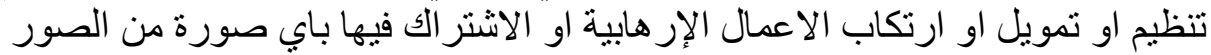

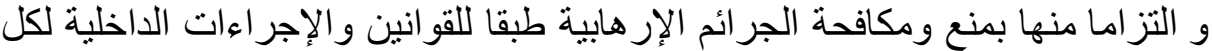

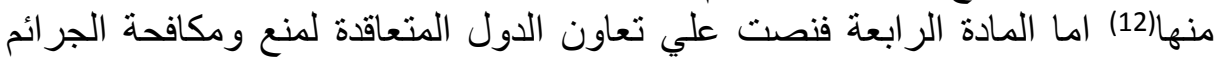

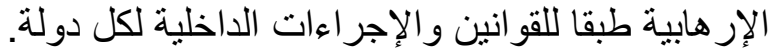
ثالثا: الاتفاقية العربية لمكافحة غسيل الإنيل الأموال وتمويل الإرهاب دابلة

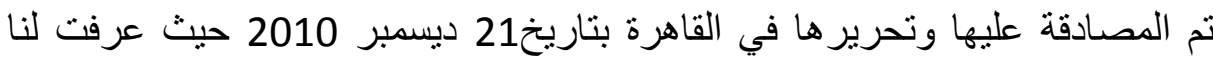

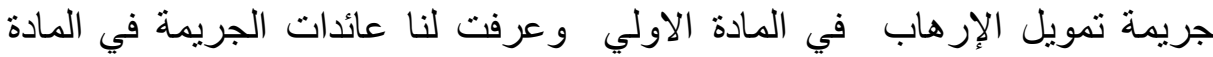

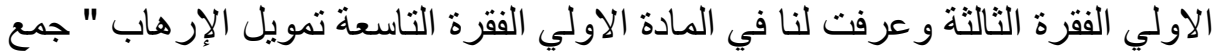

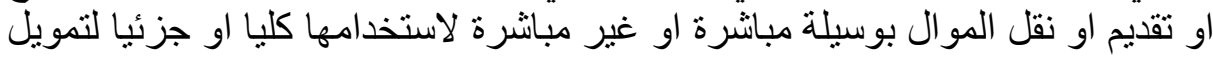

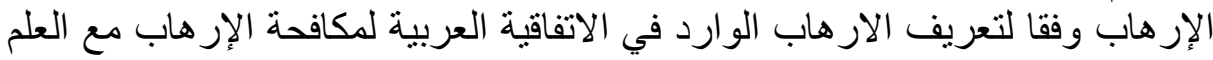

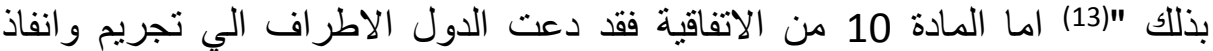
الافعال النالية في قو انينها وهي:

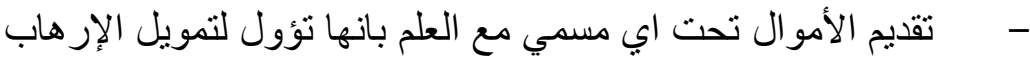

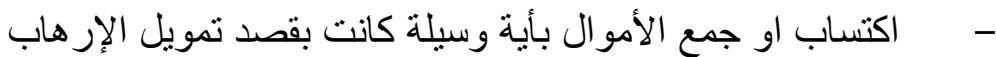

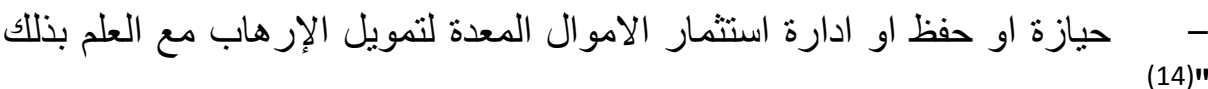
كل هاته الاعمال تعتبر في نظر الاتفاقية جريمة تمويل الإرهاب.

الفرع الثاني: مدي تأثر المشرع الجزائري بالقانون الاولي في تجريم تمويل الإرهاب

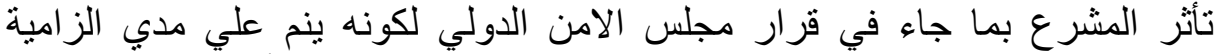

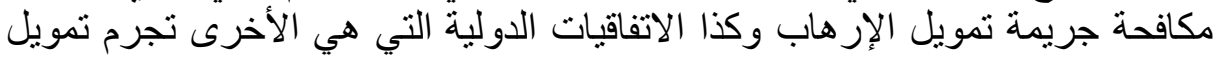

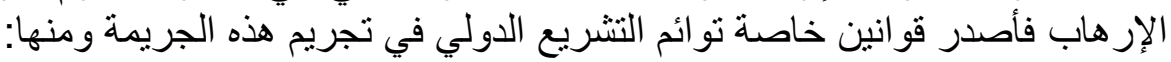


أولا: القانون الخاص بتجريم تمويل الإرهاب رقم 05 -01 مؤرخ في2005

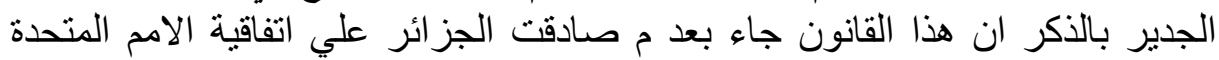

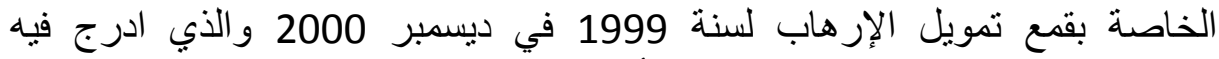

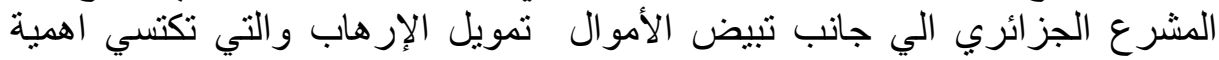

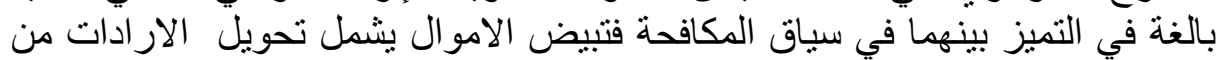

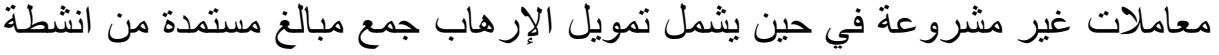

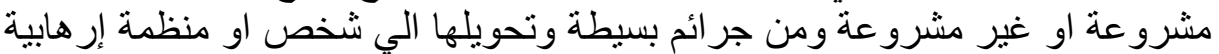

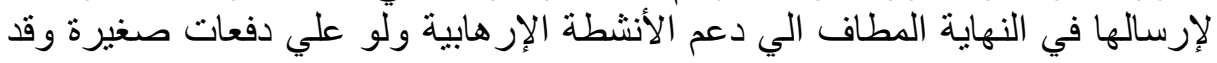

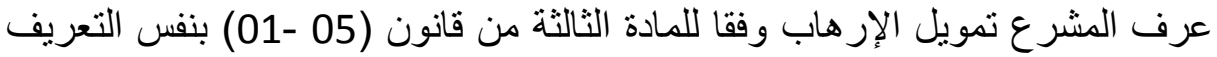

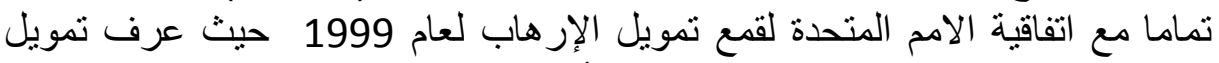

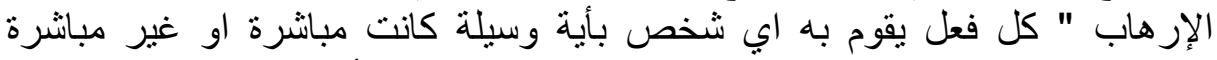

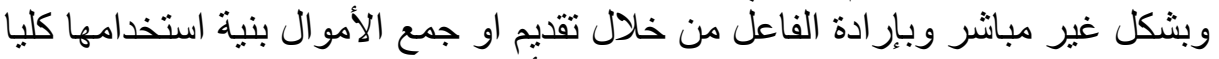

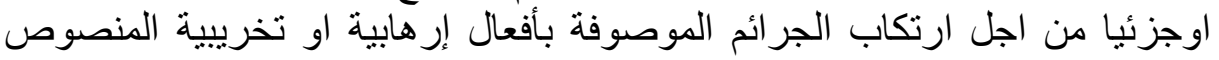

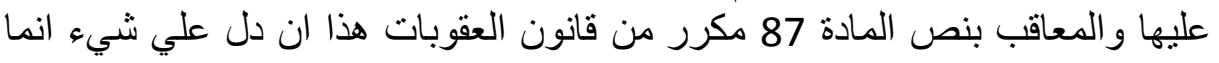

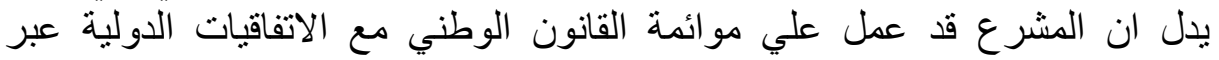

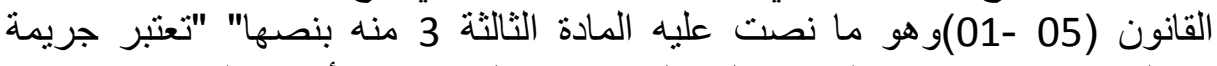

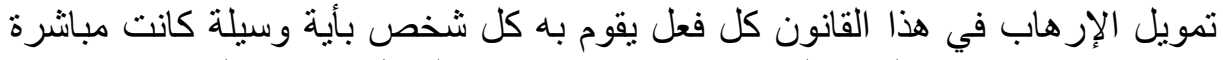

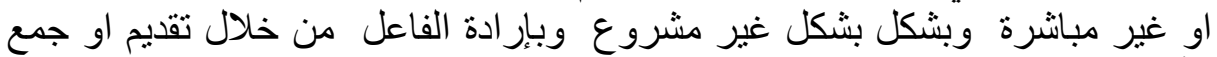

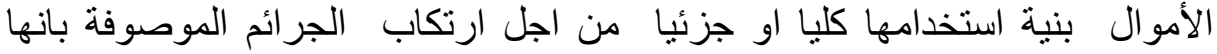

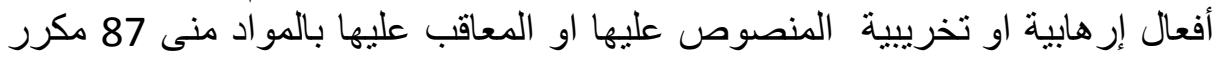

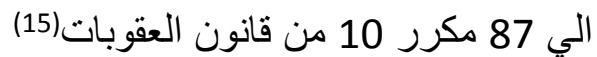

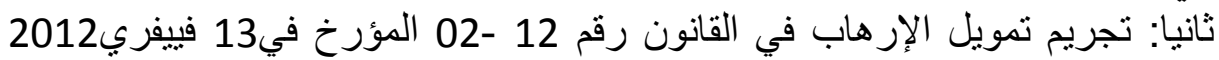

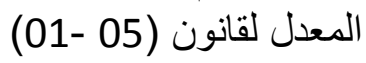

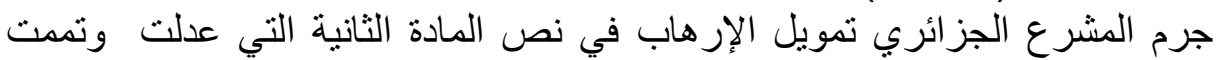

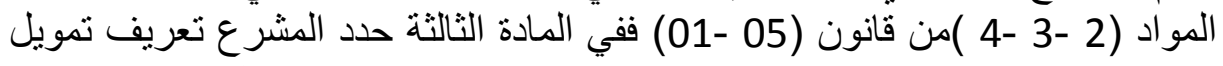

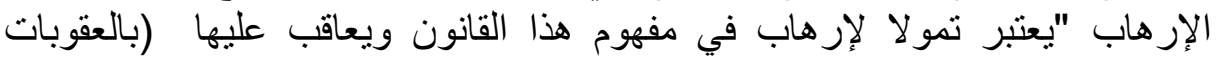

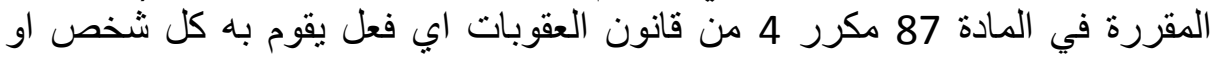

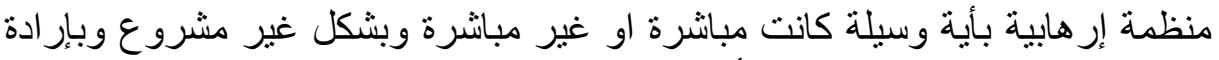

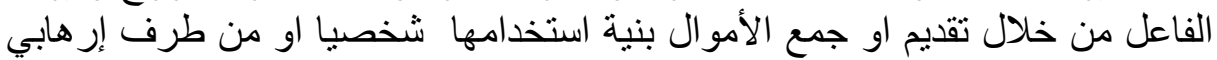

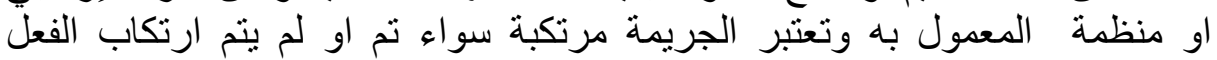

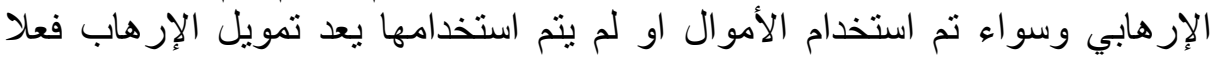

إر هابيا. (16)

ثالثا: تجريم تمويل الإرهاب في قانون رقم 15 -06 المؤرخ في 15 فيفري 2015

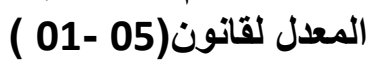

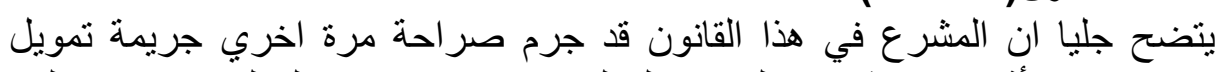

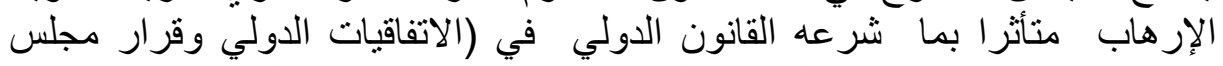

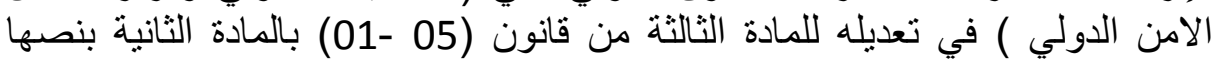

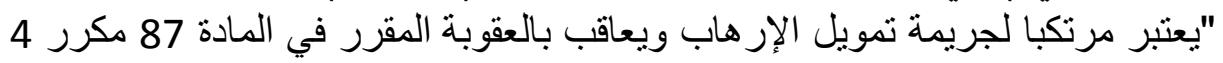

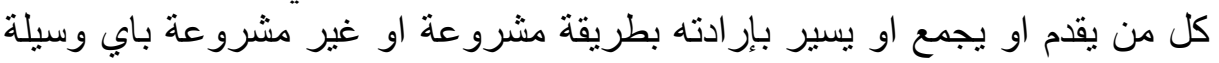

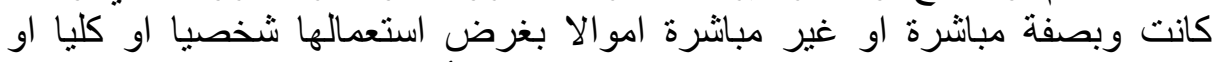
جزئيا لارتكاب او محاولة ارتكاب جرائم موصوفة بأفعال إرهابية او دور مع علمه بانها 
1- من طرف إرهابي او منظمة إرهابية لارتكاب او محاولة ارتكاب جرائم موصوفة بانها جر ائم إرهابية.

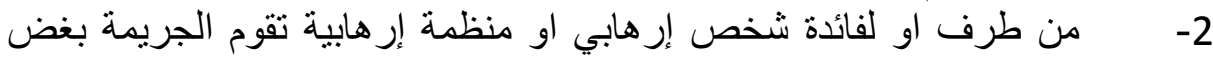

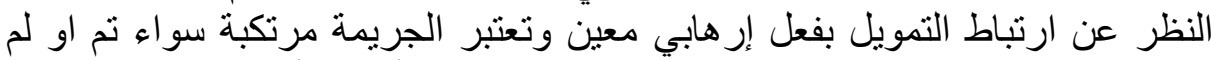
يتم ارتكاب الفعل الإرهابي وسواء تم استخدام هذه الأموال أو لم لم يتم استخدامها

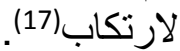

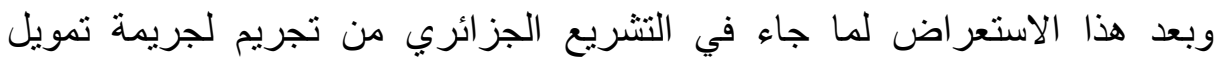
الإرهاب في مجمل قانون رقم 05 -01 و القانون رقم 12 -02 و القانون 15 -06 نقائري التول

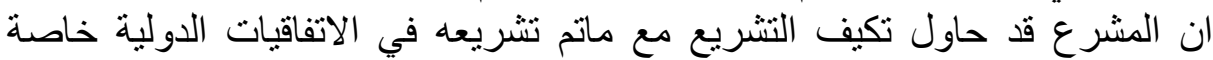

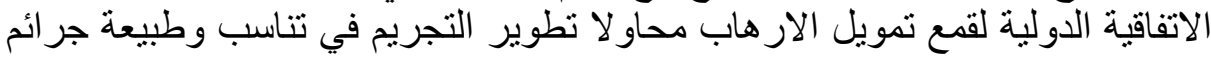

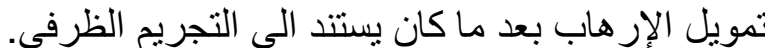

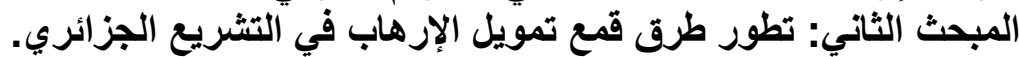

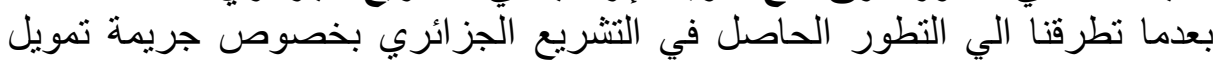

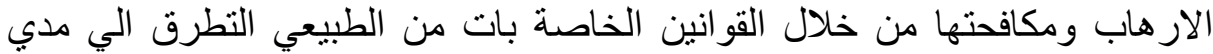

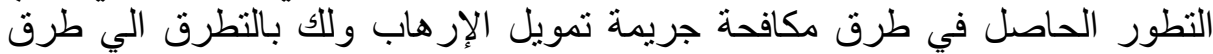

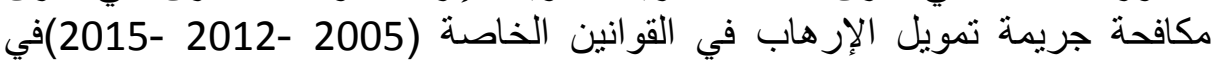

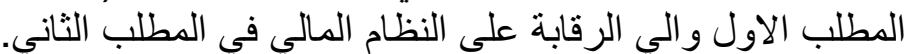

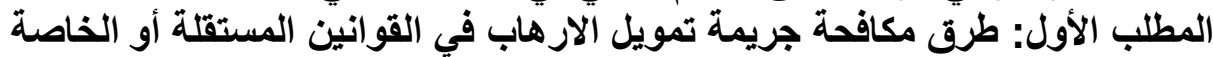

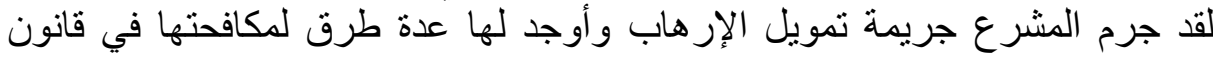

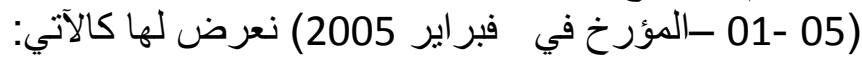
الفرع الأول: طرق مكافحة تمويل الإرهاب في القانون المستقل أو الخاص (2005)

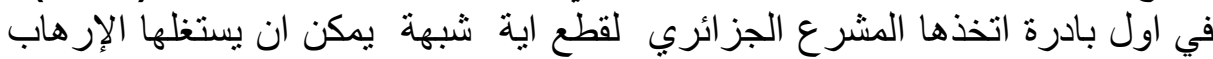

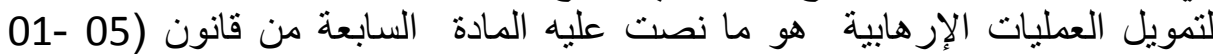

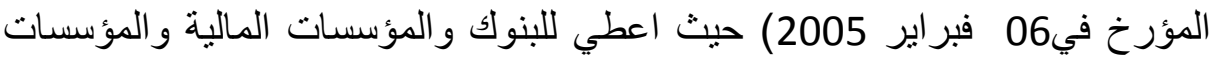

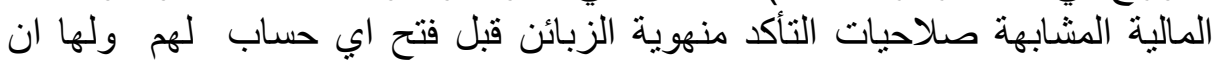

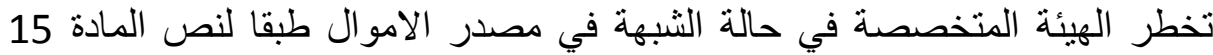

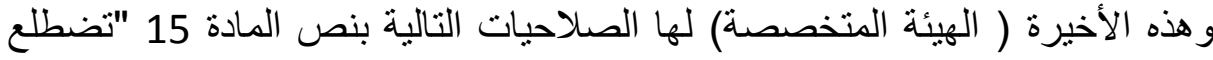

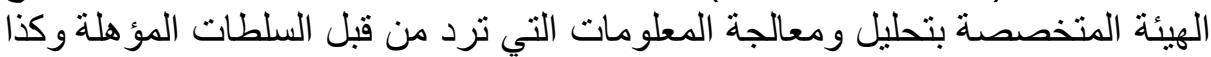
الإخطار ات بالثبهة التي يخضع لها الأشخاص المذكورة في المادة 19 (18)اما المادة المادة

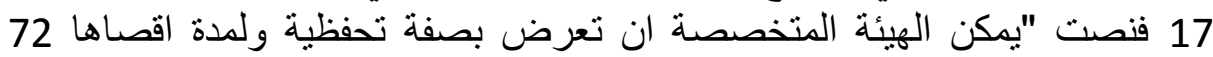

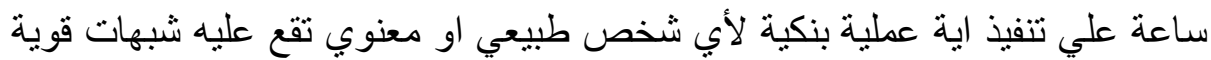

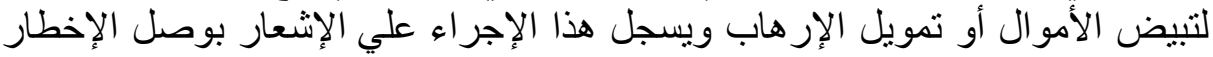

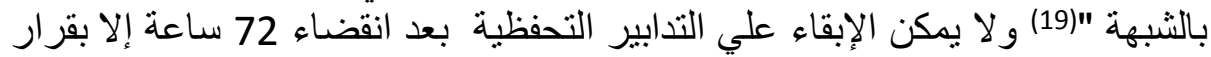

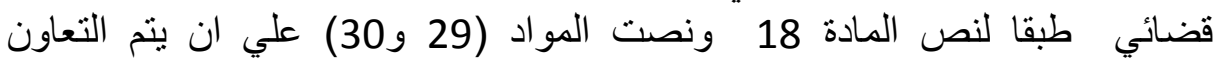

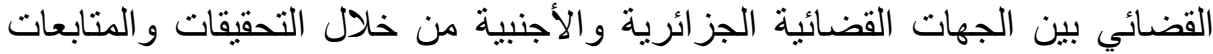

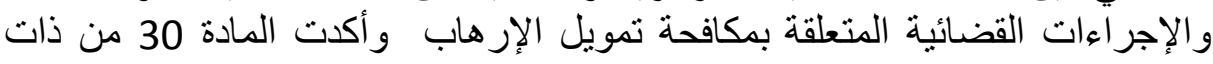

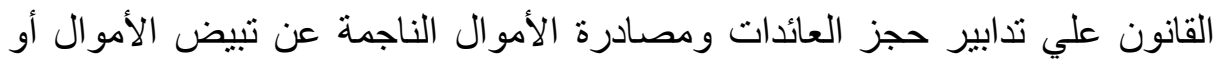

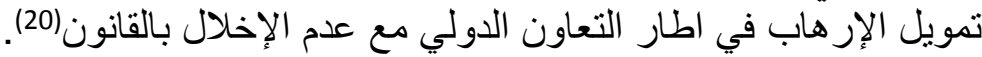
الفرع الثاني: طرق مكافحة تمويل الارهاب في الإن القانون المستقل أو الخاص الخاص (2012)

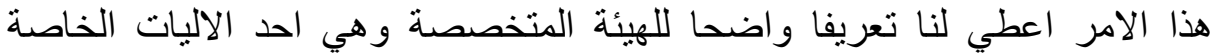

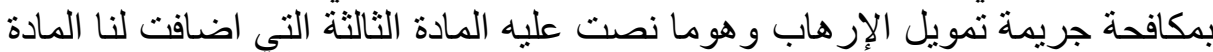

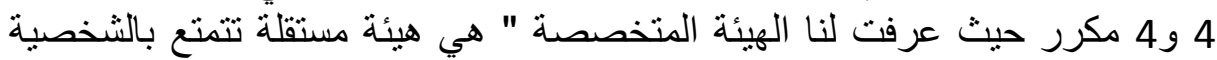


المعنوية والاستقلال المالي وتوضع لدي الوزير المكلف بالمالية ل اما المادة 4 من

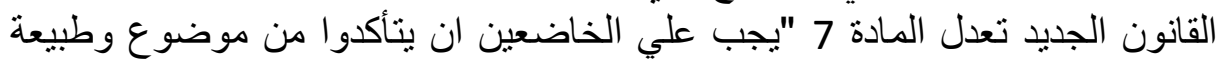

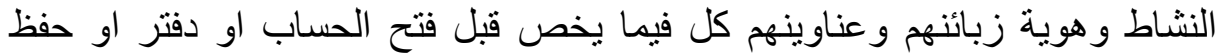

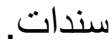

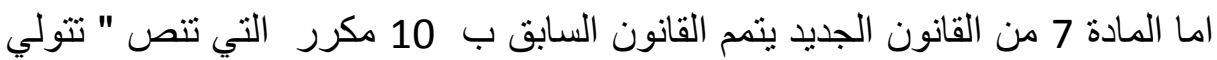

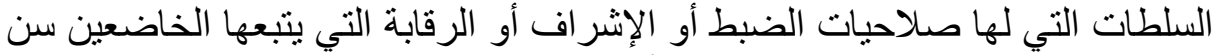

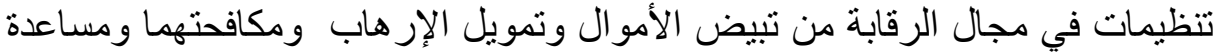

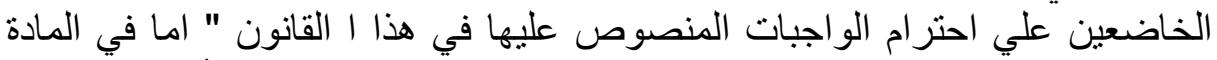

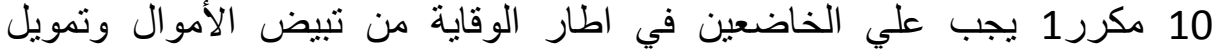

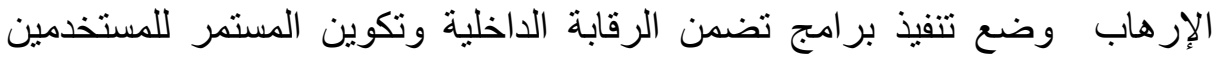

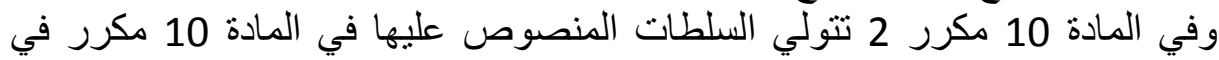

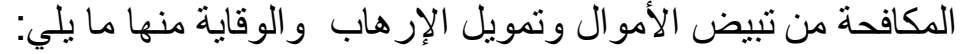

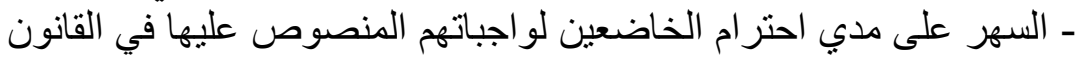

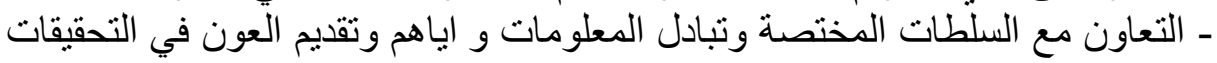

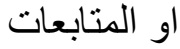
-تبليغ الهيئة المختصة دون تأخير بكل المعلومات المتعلقة بعمليات او الوقائع أوشبهة

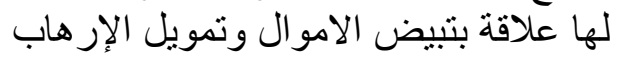

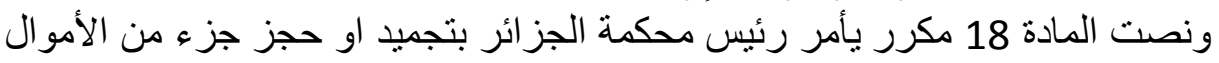

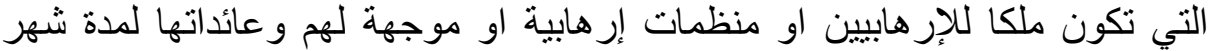

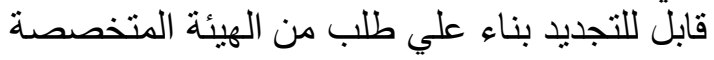

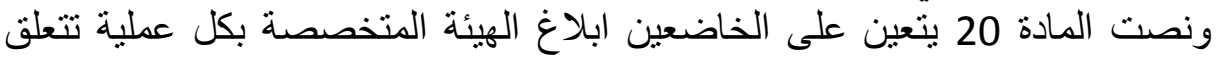
بأموال شبيهة انها متحصل عليها من جريمة او يبدو انها موجة لتبيض الأموال

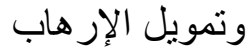
وجاء في المادة 25 في إطار التعاون يمكن ان تضطلع الهيئة المتخصصة هيئات

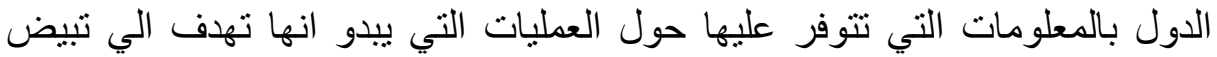

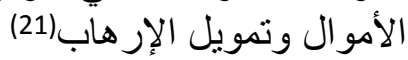
اما المادة 10 من القانون الجديد جعلت التعاون القابت القضائي الدولي في مجال التجميد

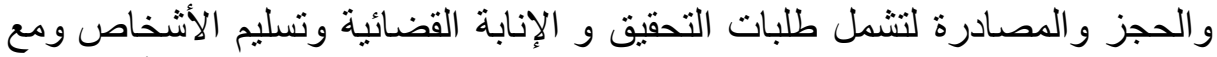

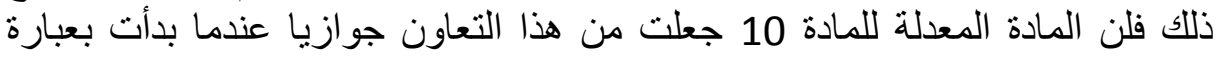

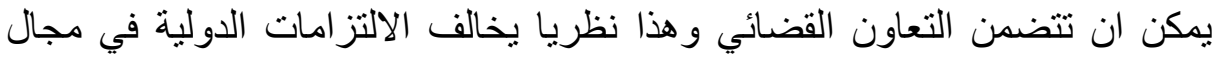

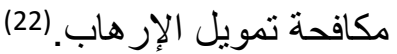

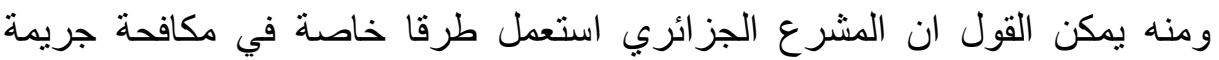
تمويل الإرهاب تمثلت في بعض التدابير التي تصدي بهن بائري للجريمة من خلال قانون 015 -01-01 المعدل بقانون 15 -

الفرع الثالث: طرق مكافحة تمويل الإرهاب في القانون المستقلة والخاص 2015

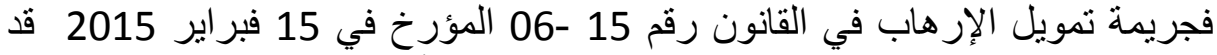

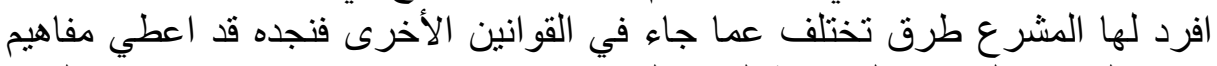

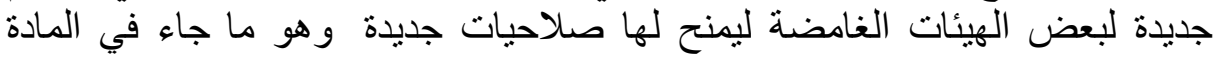

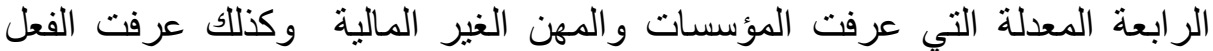

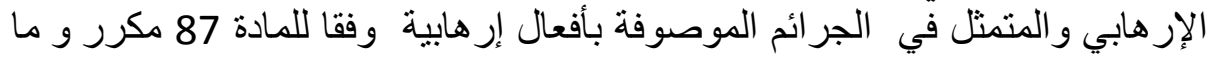

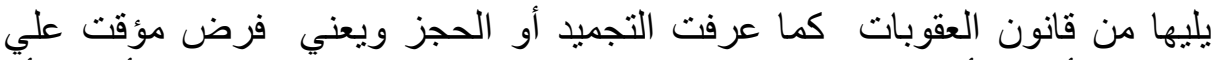

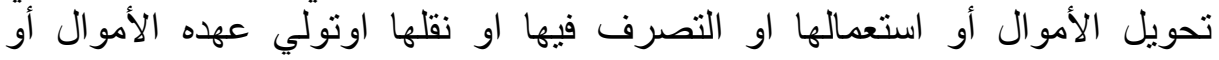

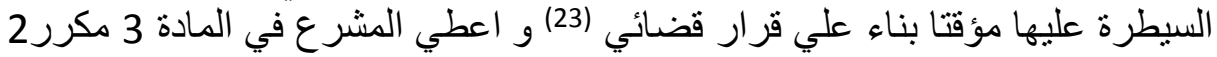




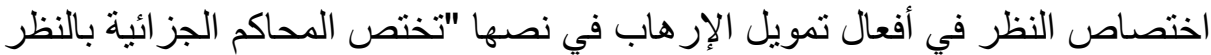

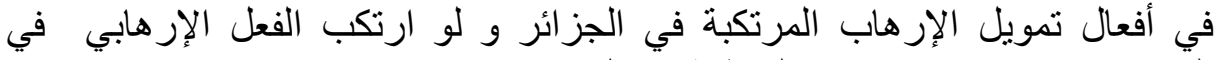

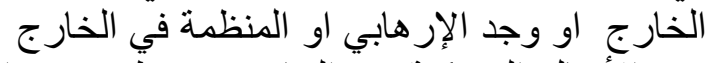

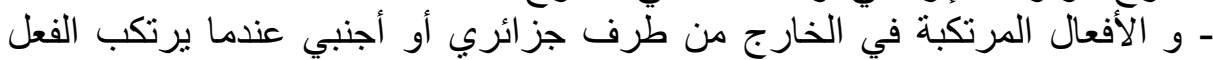

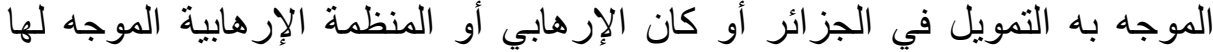

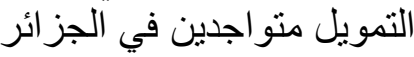

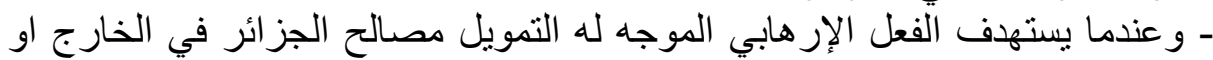

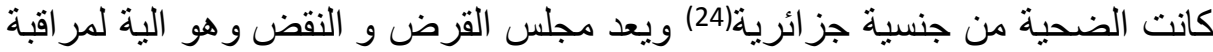

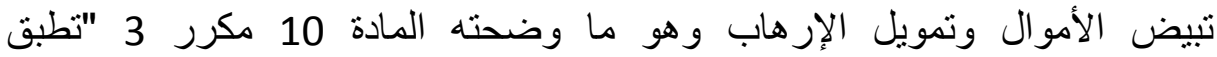

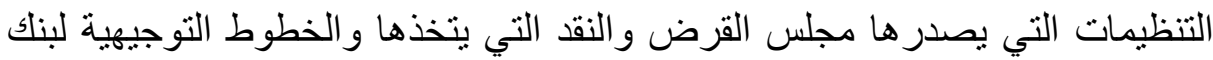

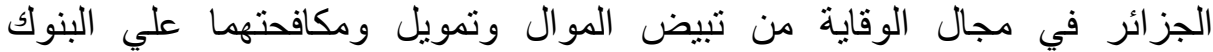

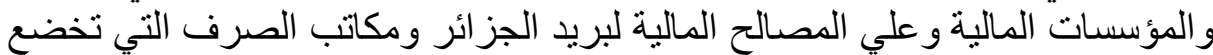

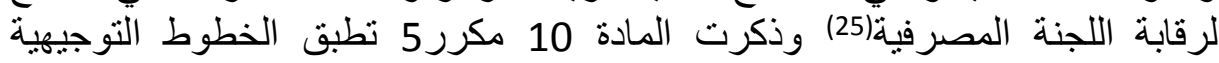

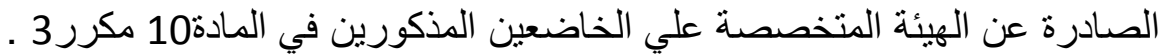

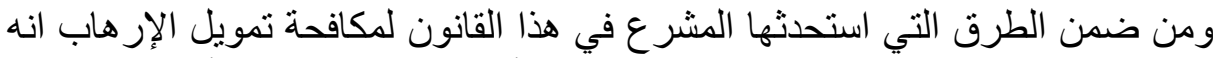

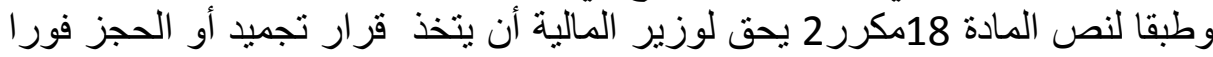

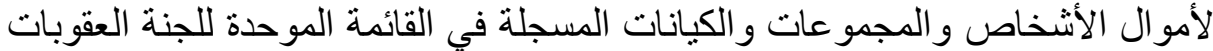

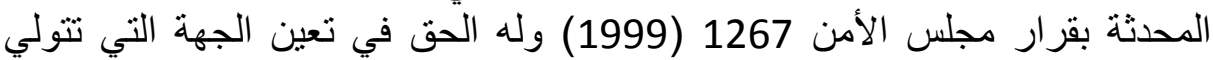

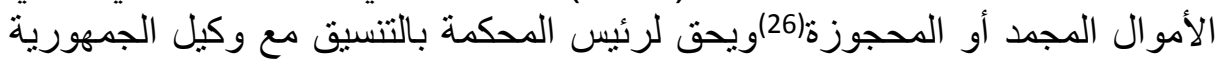
أن يأذن لمن شملهم قرار التجميد استعمال جزء من أموال الموالهم بتغطية احتياجاتهم

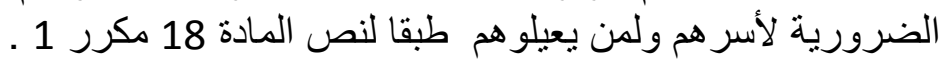

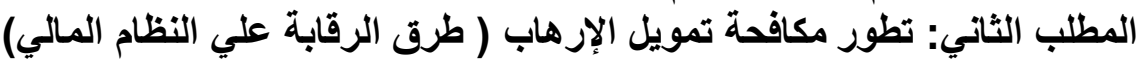

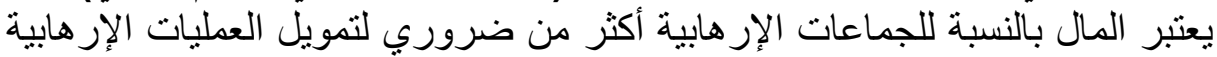

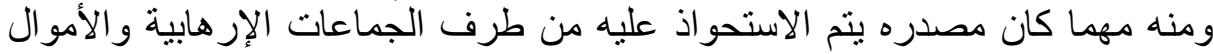

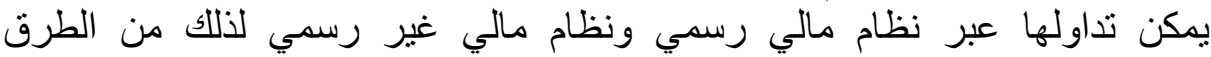

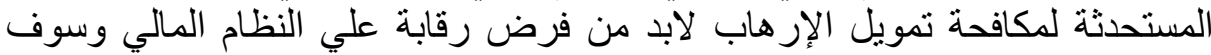

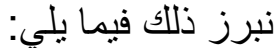
الفرع الأول: فرض الرقابة على تنقل او تحويل الأموال عبر النظام المالي الرسمي

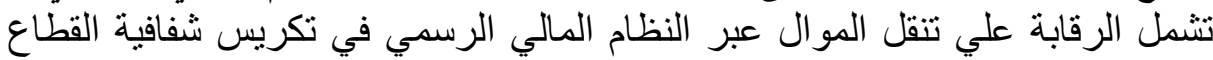

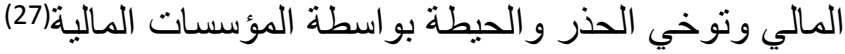

1

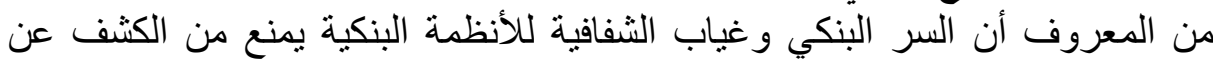

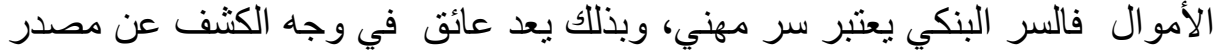

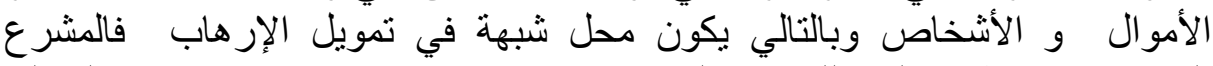

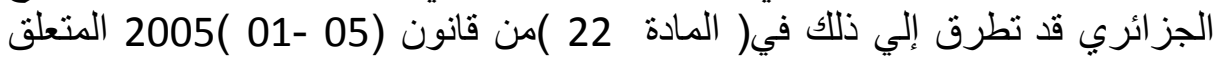

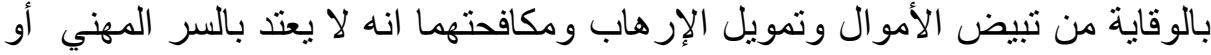

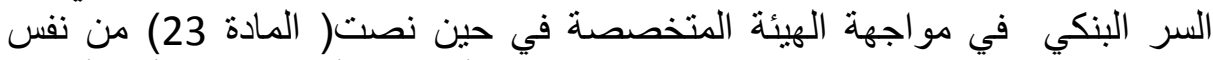

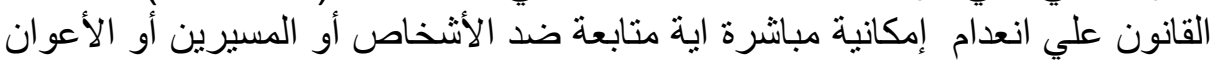
بسبب انتهاكهم السر المهني او البنكي. (28) 
2 - توخي الحذر والحيطة بواسطة المؤسسات المالية

تتضمن هذه الطريقة صورتان هي التعرف علي الزئسن الزبون والالتز ام بالرقابة و الاستعلام

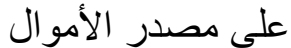
تعزف علي الزبون

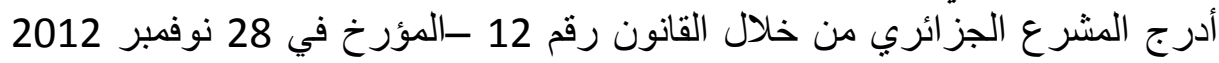

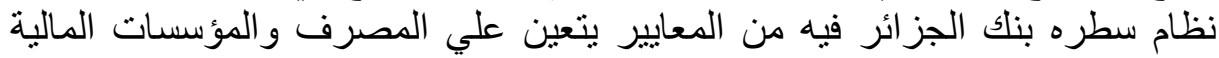

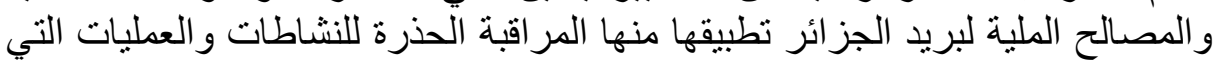

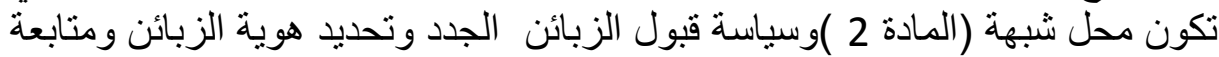

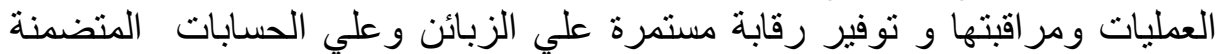

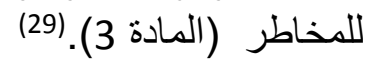

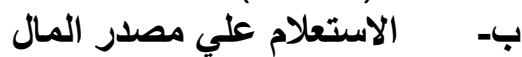

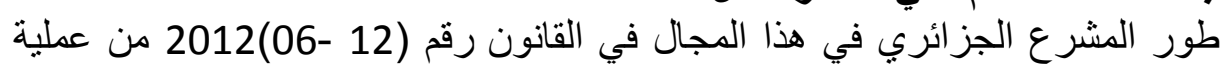

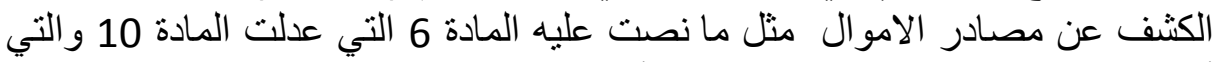

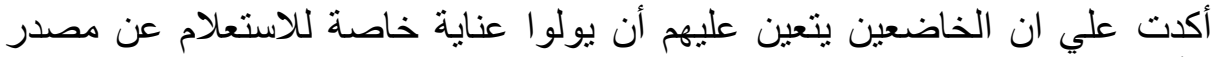

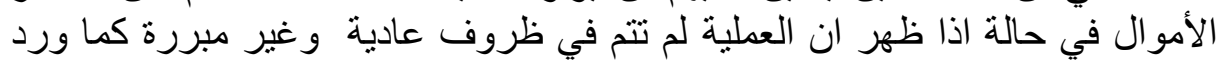

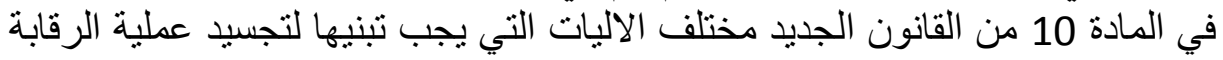

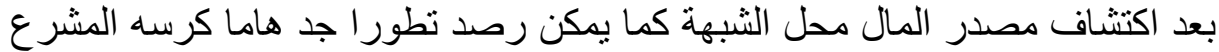

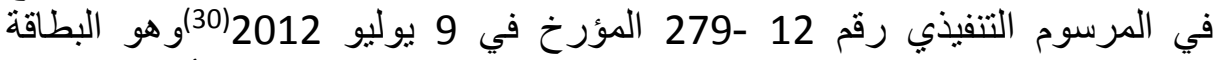

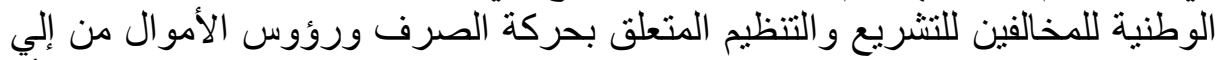

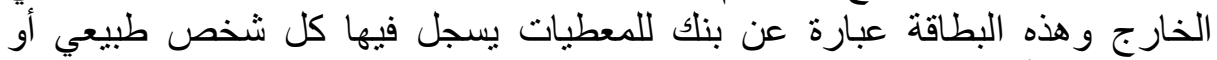

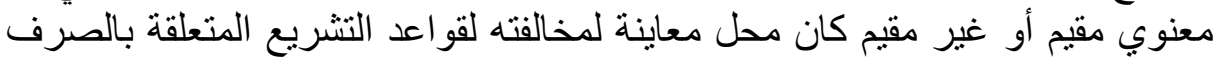

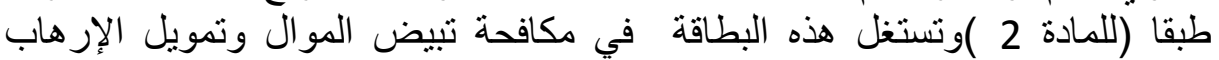

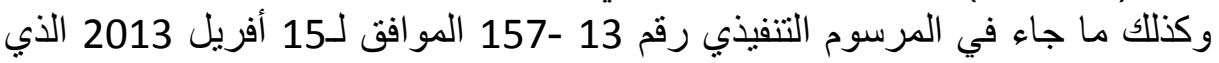

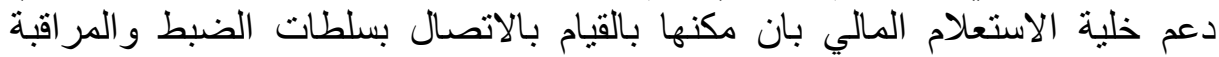

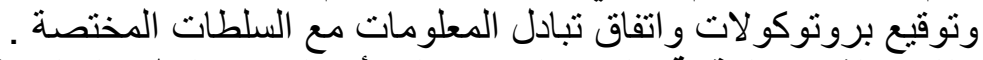

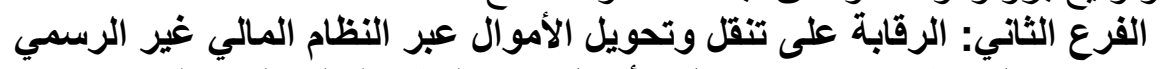
تتعدد وسائل وطرق نقالا و تحويل الأموال عبر النظام المالي الغير الرسمي ومنها مالئ الريا يلي:

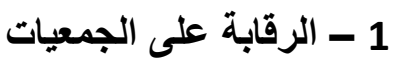

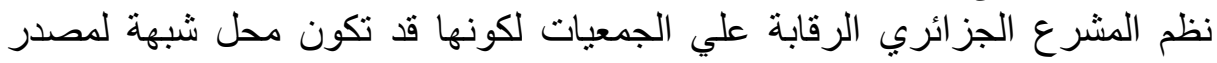

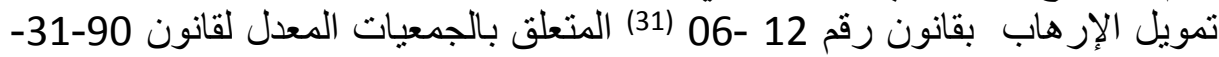

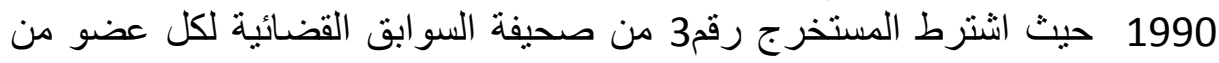

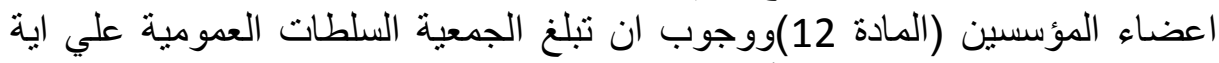

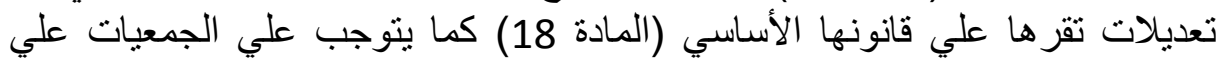

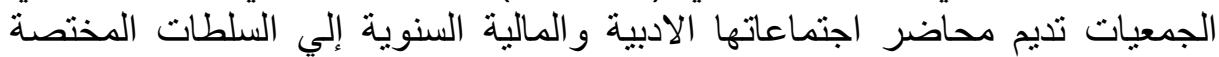

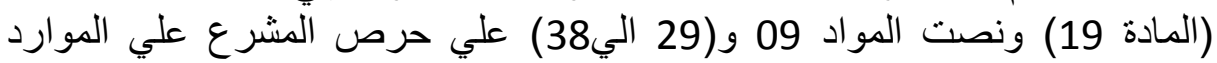

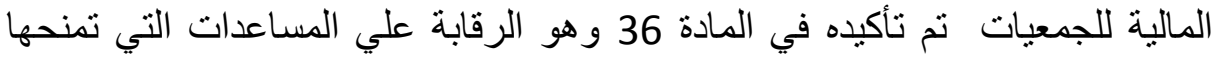

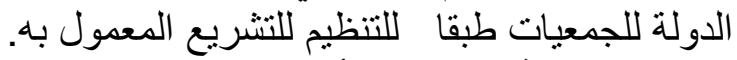

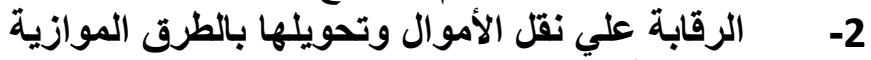

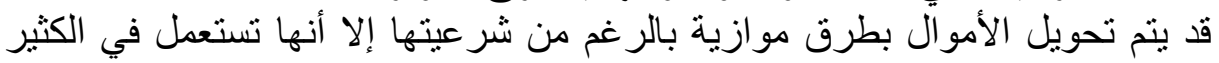

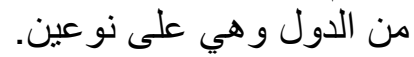


أ- الأنظمة الموازية التقليدية

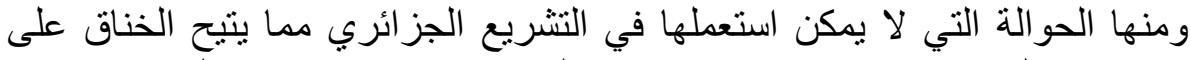

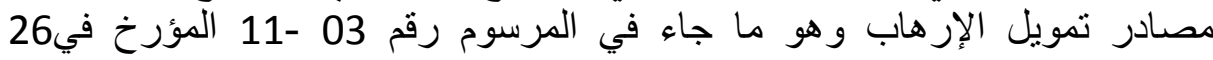
اغسطس 2003(32)المتعلق بالمعاملات والاعتمادات الذي لا يجيز التعامل بها ويعاقب

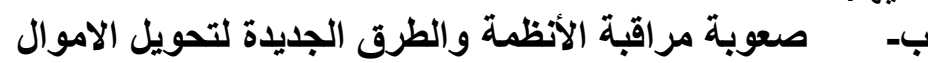

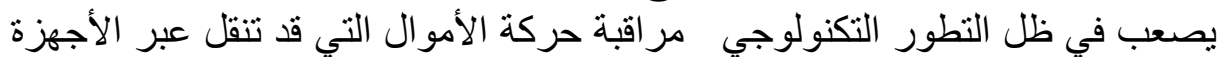

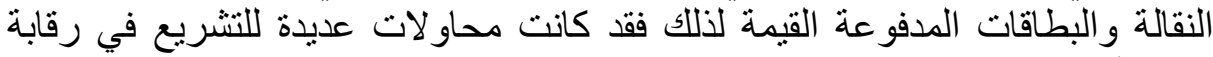

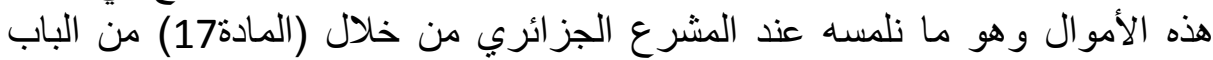

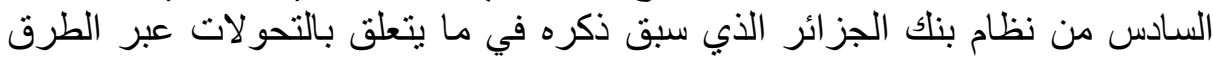
الجديدة حيث تم ادر اج بعض التدابير المتعلقة بالتحو لات الالكترونية.

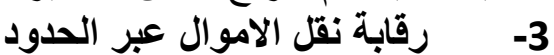

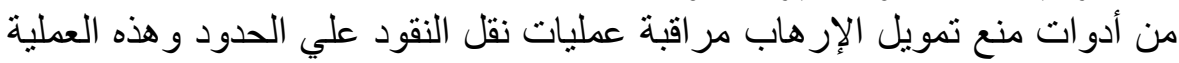

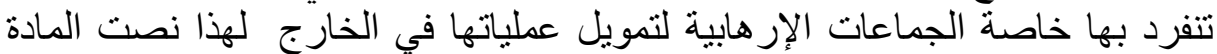

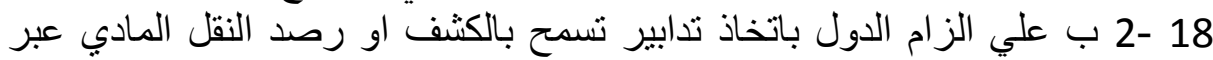

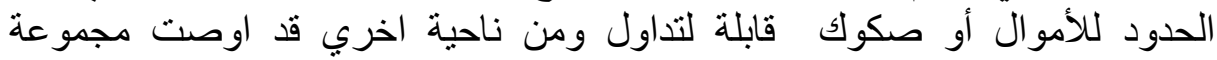

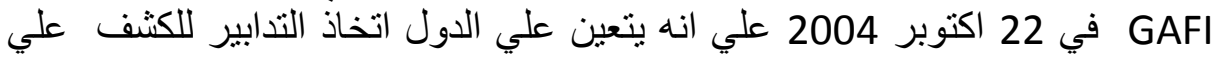

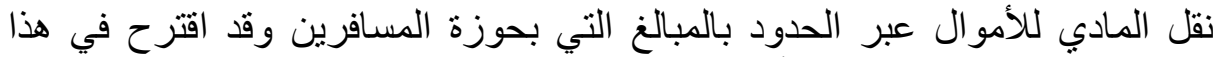

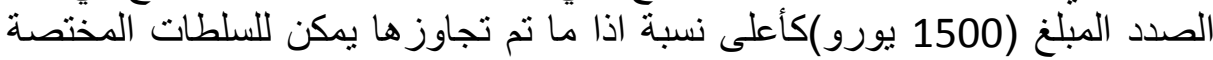
استجو اب المسافرين الحاملين لتلك المبالغ.

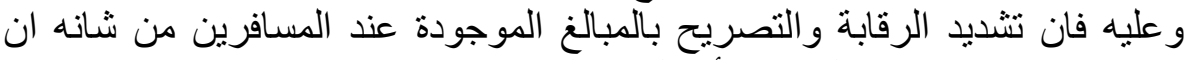

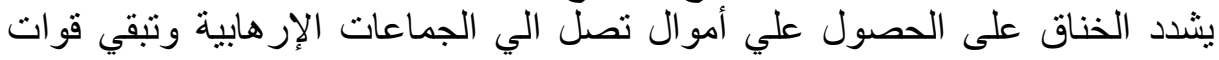
حرس الحدود من يتولى هذه العملية. (33) الخاتمة

جريمة تمويل الإرهاب جريمة مستحدثة تصدي لهاب المجتمع الدولي بالمكافحة عبر

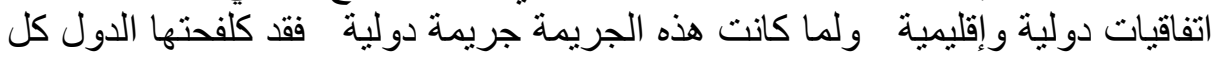

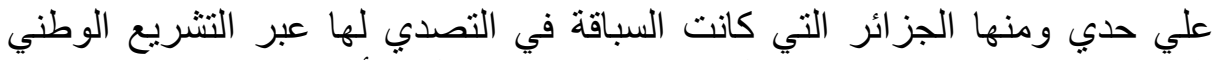

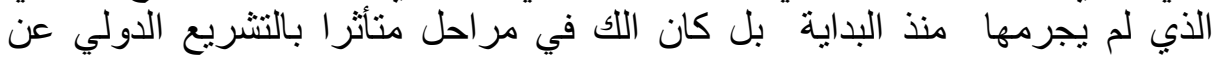

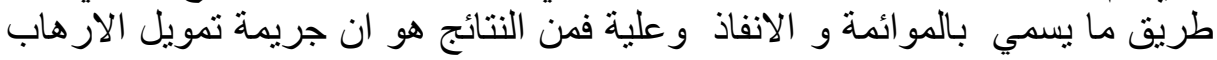

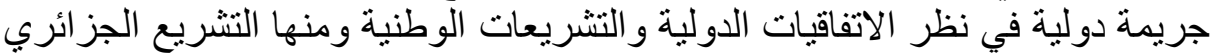
الذي نص علي ذلك، ويمكن أن نستتتج ما يلي :

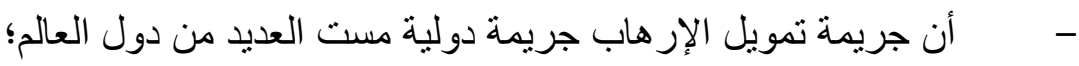

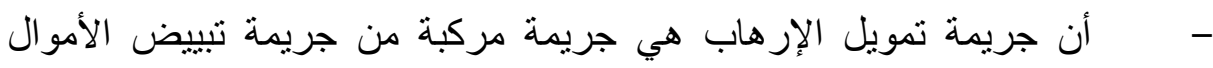

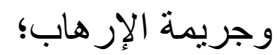
وما يمكن اقتر احه يكون كالأتي:

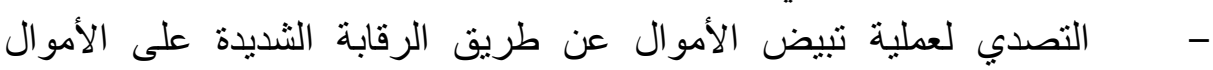

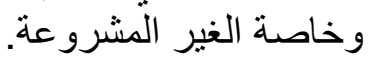
- - مالتشريع الدوري بقوانين لمكافحة هذه الجريمة في محاولة مواكبة تطور الأساليب المستحدثة في الإجرام.

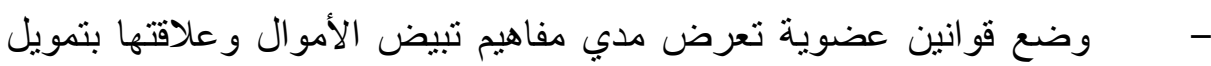

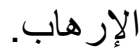


- م تجفيف منابع تمويل الإرهاب يستدعي وضع سياسات عامة وواضحة لمكافحة هذه الجريمة سواء كان على المستوي الوطني أو الدولي.

(1)- للمرسوم التشريعي رقم 92 -03 -المؤرخ في 30 سبتمبر 1992 المتعلق بمكافحة التخريب و الإر هاب.

(2)-المادة 87 من قانون العقوبات المعدل بالأمر رقم 95 -10 -المؤرخ في 25 -02 1995.

(3)-المادة 87 مكرر من قانون العقوبات المعدل بالأمر رقم 95 -10 -المؤرخ في 25 -02 1995(4)-الأمر رقم 12 -02 المؤرخ في 13 فيفري 2012 (5) 2012.

(5)-لمادة 87 مكرر من قانون العقوبات المعدل بالقانون رقم 14 -01-01-المؤرخ في 4 فيفري2014. (6)-المادة 87 مكرر 11 من قانون العقوبات المعدلة بقانون رقم 16 -02 المؤرخ في 16 يونيو 2016. (7)-قرار مجلس الامن الدولي رقم 1373 (2001) بتاريخ 28 سبتمبر 2001 إنشاء لجنة مكافحة الإرهاب (8)_المادة 03 من الاتفاقية الدولية لقمع تمويل الإرهاب.

(9-)Jean christophe martin les règles internationales relative a la lute contre le terrorisme travaux du ceriscbrylant paris 2006

(10)ـالمادة الثانية الققرة الاولي من اتفاقية الدولية لقمع تمويل الإرهاب لعام 1999.

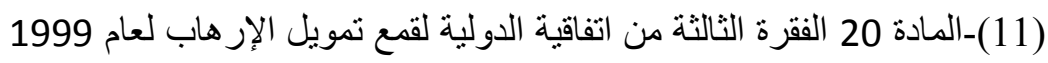

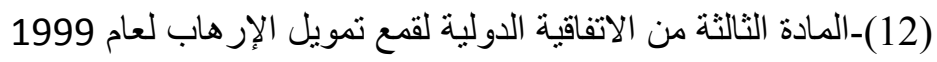

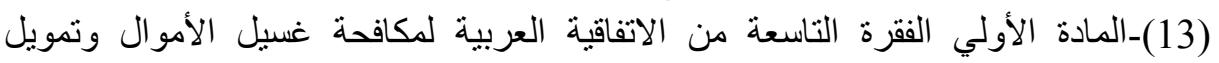

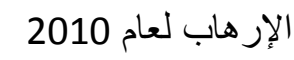

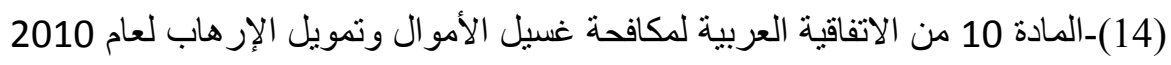
(15)-المادة 03 من قانون رقم 15 -06 الانفة المؤرخ في 2015 المعدل لقانون رقم (05 -01 2005

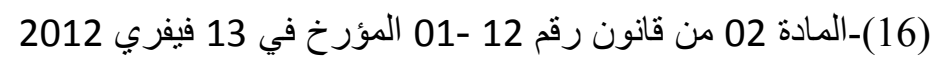

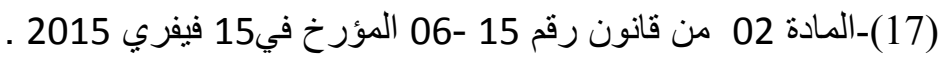

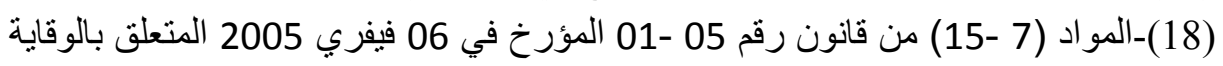
من تبيض الأمو ال وتمويل الإرهاب.

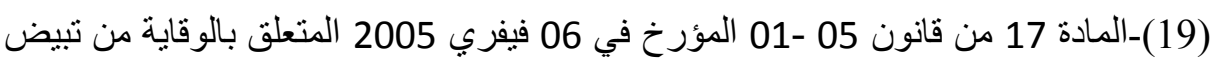

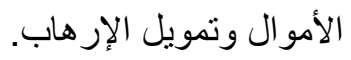
(20)-قريبيز مراد ، مكافحة الإرهاب بين القانون الدولي والتشريعات الوطنية أطروحة

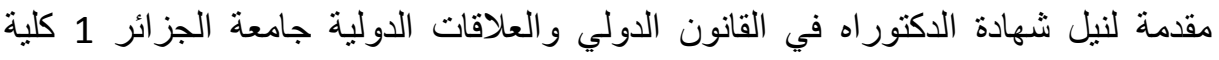
(21)-المو اد (4-78-20-25) من القانون رقم 12 -06 المؤرخ في 13 فيفري 2012 
(22)- projet de disposition législatives modelés contre le terrorisme service de prévention du terrorisme guide pour l'interpolation législatives et la mis en œuvre les instrumentions universels contre le terrorisme unodc vienne novembre 2008.

http://www.unodc.org/tldbpdf/unmodellawmlatranslationfrpdf.

$$
\begin{aligned}
& \text { (23)-المادة } 04 \text { من قانون رقم } 15 \text {-06 المؤرخ في } 15 \text { فيفري } 2015
\end{aligned}
$$

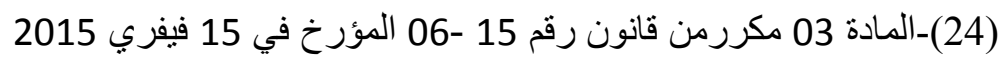

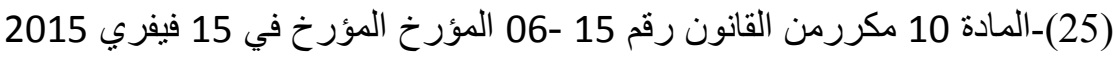

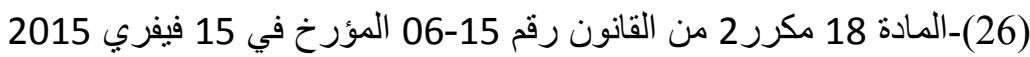

(27) projet de disposition législatives modelés contre le terrorisme service de prévention du terrorisme guide pour l'interpolation législatives et la mis en œuvre les instrumentions universels contre le terrorisme unodc vienne novembre 2008.

http://www.unodc.org/tldbpdf/unmodellawmlatranslationfrpdf.

$$
\begin{aligned}
& \text { (28)-المادتين ( 22- 23)من قانون رقم } 05 \text {-01 المؤرخ في } 6 \text { فيفري } 2005 \text { المتعلق } \\
& \text { بالوقاية من تبيض الموال وتمويل الارهاب }
\end{aligned}
$$

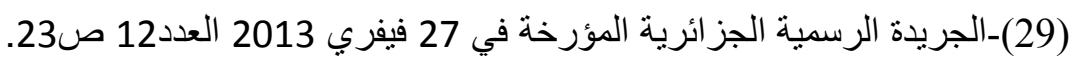

$$
\begin{aligned}
& \text { 2012.2013)-المرسوم التنفيذي رقم } 12 \text {-279 المؤرخ في } 9 \text { يولئه } \\
& \text { (31)-القانون رقم } 12 \text {-06 المؤرخ في } 12 \text { يناير } 2012 \text { المتعلق بالجمعيات الجريدة الرسمية } \\
& \text { الجز ائرية المؤرخة في } 15 \text { يناير } 2012 \text { العدد } 2 . \\
& \text { (32)-المرسوم رقم } 03 \text {-11 المؤرخ في } 26 \text { اب الغورة المسط } 2003 \text { المتعلق بالمعاملات }
\end{aligned}
$$

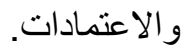

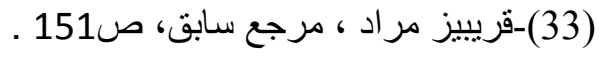

$$
\begin{aligned}
& \text { المراجع: المراجع بالعربية } \\
& \text { - - احسن بوسقيعة، الوجيز في القانون الجزائي العام، الطبعة العاثرة العزبة 2011، دار هومة }
\end{aligned}
$$

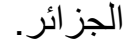

$$
\begin{aligned}
& \text { - محمد منولي، التخطيط الاستراتيجي في مكافحة جرائم الإرهاب الدولي دراسة } \\
& \text { مقارنة، لجنة التأليف التعريب و النشر ، جأمعة الكويت } 2006
\end{aligned}
$$

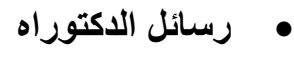

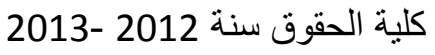

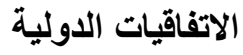




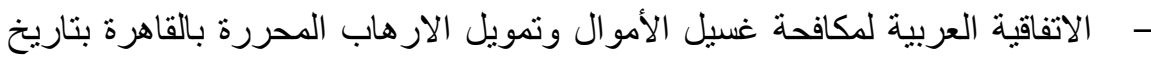

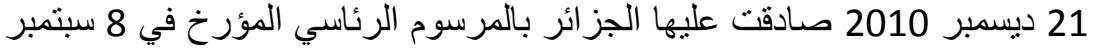
2014 الجريدة الرسمية عدد55 بتاريخ 23 سبتمبر 2014 • أهم النصوص القانونية

- - فانون رقم 05 -01 المؤرخ في6 فيفري 2005 المتعلق بالوقاية من تبيض الأموال

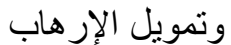
- - قانون رقم 15 -06 المؤرخ في 2015 المعدل لقانون رقم (05 -01 -2005 - القانون رقم 12 -06 المؤرخ في 12 يناير 2012 الموني 2012 المتعلق بالجمعيات الجريدة الرسمية الجزائرية المؤرخة في 15 يناير 2012 العدد 2 ـ 2012

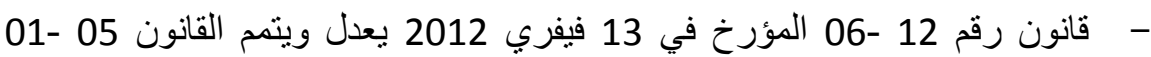
المؤرخ في 6 فبر اير 2005 المتعلق الوقاية من تبيض الأموال وتمويل الإرهاب.

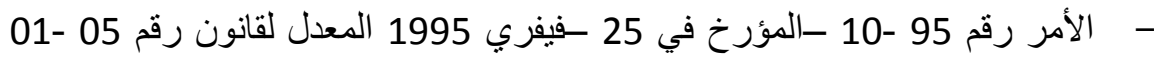
ـالمؤرخ في 6 فيفري 2005 المتعلق بالوقاية من تبيض الامو ال وتمويل الإرهاب.

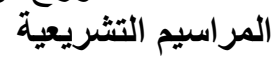

- المرسوم التشريعي رقم 92 -03 المؤرخ في 30 سبتمبر 1992 المتعلق بمكافحة التخريب والإرهاب الجريدة الرسمية للجمهورية الجزية ائرية الديمقراطية الشعبية العدد 70 المؤرخة في 01 اكتوبر 1992 المراسيم التنفيذية - - المرسوم التنفيذي رقم 12 -279 المؤرخ في 9 يوليو 2012 - 2011 - - المرسوم رقم 03 -11 المؤرخ في في 26 اب اغسطس 2003 المتعلق بالمعاملات و الاعتمادات

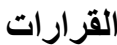

قرارات مجلس الأمن الدولي

- - 1373 -2001 ) بتاريخ 28 سبتمبر 2001 إنشاء لجنة مكافحة الإرهاب

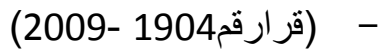

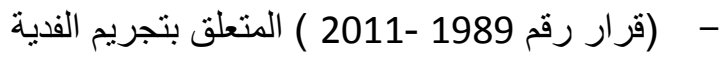

\section{2 - 202 - المراجع بالفرنسية}

1) jean Christophe martin les règles internationales relative a la lute contre le terrorisme travaux du cericbrylaant paris 2006

2) Projet de disposition législative modelés contre le terrorisme service de prévention du législatives et la mise en œuvre les instruments universels contre le terrorisme unodc vienne novembre 2008

http://www.unodc.org/tldbpdf/unmodellawmlatranslationfrpdf . 
